\title{
Onomastical analysis of inscriptions from Koper and its vicinty
}

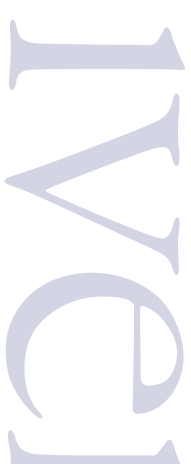

\author{
Vladimir Kusik
}

The article gives an onomastical analysis of twenty-four inscritpions found in or in the vicinity of Koper, all of which are already published in the relevant corpora of Latin texts. Origin of the people mentioned in the inscriptions include indigenous population romanized to certain extent, orientals, westerners and immigrants from other parts of Italy. All inscriptions are dated to the period of the Principate.

Keywords: Aegida, Koper, onomastics, romanization,epigraphy
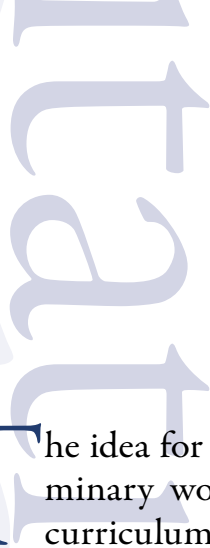

$\mathrm{T}$

he idea for this article originated as a seminary work which was a part of the curriculum during the authors stay at the University of Primorska within the student exchange programme. As the scope of the work grew, Dr. Gregor Pobežin suggested and provided professional guidance to further analyze the names of the inhabitants of Aegida (todays Koper) mentioned on the inscriptions found in Koper and its vicinity.

All the monuments are already published ${ }^{2}$ and although it has been written about the po-

An article about the names found in Volčji Grad served as a starting point for this work, see Gregor Pobežin, "Nagrobnik s cerkve sv. Janeza Krstnika na Volčjem Gradu (CIL V 712) ", in Volčji grad, ed. Mitja Guštin (Komen: Občina Komen, 2012), 59-67.

2 Attilio Degrassi, Inscriptiones Italiae, Vol. X., Regio X, Fasc. IIIHistria septentrionalis (Roma: La libreria dello Stato, 1936).

pulation of Aegida in antiquity, ${ }^{3}$ an onomastical analysis of each monument can further contribute to the knowledge of this subject. Throught it, not only the origin and the frequency of the name in the Empire is given, but also the social, legal and in some rare cases geographical information about the inhabitants of Aegida. Each momunent analyzed in the article is presented with the nature of its finding, the information of its whereabouts and the place of keeping. The inscriptions are translated, each part of the name of the person mentioned is analyzed and all available information that can be discerned is presented. The monuments are dated on the basis

Attilio Degrassi, Abitati Preistorici E Romani Nell'agro Di Capodistria E Il Sito Dell'antica Egida, (Parenzo: G. Coana \& Figli, 1933); Alka Starac, "Pitanje istočne granice Cisalpinske Galije i odnos općina Tergeste i Egida”, Histria Archaeologica 24-25 (1993-1994): $5-57$.

DOI: HTTPS://DOI.ORG/I0.26493/2350-5443.3(2)69-98 
of epigraphical features if possible and crossreferrencing with the entries in the relevant databases.

\section{Short history of Aegida and its epigraphical monuments}

The city of Koper in the Slovenian part of Istria is situated on the coast and a small island south of the Rižane river. Today, the island is the place where the historical center of Koper stands. In antiquity, it was location where the Roman town of Aegida was built. ${ }^{4}$

First mention of Aegida in the historical sources is found in Elder Plinys Naturalis Historia. ${ }^{5}$ The name Aegida is a Greek word for a goat, as is Capris, a later Latin name of the settlement which was used from the 7 th century AD. It is possible that both the Greek and Latin names of the town are the direct translation of a native word for goat. Other names included in the sources, maps and itiniraries are: Iustinopolis, Caprae, Capris, Insula Caprea or Capritana insula, so it is not surprising that the modern Slovenian name for Koper can be derived from its Latin root. ${ }^{6}$

The settlement on the Koper island was built probably in the beginning of $\mathrm{I}^{\text {st }}$ century $\mathrm{BC}$ and during the next hundred years, Aegida acquired characteristics of an urbanized Roman town. Accoridng to Pliny, at the latest from the time of Augustus Aegida was oppidum civium Romanorum, which can be considered that it held the rank of municipium. ${ }^{7}$ With the constitution of a municipium, Aegida was enrolled in the voting disctrict of the tribe Pupinia, same as nearby Tergeste. In I8 - I2 BC the area from Rižane (Formio) up to Raša (Arsia) river was incoporated into Italy. After the initial growth and

4 Radovan Cunja, "Koper, Kapucinski vrt", Arheološki pregled (1986) 1987:118-120; Matej Župančičc, "Sermin ob Rižani, pretres virov in arheoloskih podatkov", Arheološki vestnik 36 (1985): 315-325; Matej Župančič, "Inter utrumque tuta" in Koper zwishen Rom und Venedig, ed. Matej Župančič (Koper: Regionalmuseum Koper, 1991) 6-II.

$\mathrm{HN}_{3 .} \mathrm{I} 29$

6 Rav. Ann. 4. 31, 5.14; Jaroslav Šašel, "Koper”, Arheološki vestnik 25 , (1976): 446-460.

7 Mate Suić, Anticki Grad Na Istocnom Jadranu (Zagreb: Sveučilišna naklada Liber, 1976), 34 . development into an urban settlement, it seems that from the time of Pliny to late antiquity, Aegida lost its importance. It is not mentioned in the itineraries, maps or historical sources. It is possible that this absence from is related to its reduced traffic importance and not with its loss of self-governing status. The fact that Aegida was not granted the rank of colony is further proof that the town experienced a period of slowed growth in every sense. $^{8}$

Roman inscriptions found in Koper are quite numerous, considering the size and importance of the town. However, the nature of their finding poses a significant problem in interpeting them and using the information for reconstructing the history of Aegida. They were not found in the archaeologically relevant context and due to renaissance and humanistic tendecies of collecting Roman monuments in private collections, the information about their true origin is practically unknown. Authors have pointed out that there is no proof that any of the monuments from Koper or its vicinity were found on the island itself, where ancient Aegida stood.'

The history of the monuments, comprised mostly by Mommsen and Kandler who tracked and transcribed them, later to be published by Degrassi in Inscriptiones Italiae for Regio $X$, reveals that majority of them were found built in public buildings of Koper, e. g. Episcopal palace, city walls, cathedral, other churches, curia or laying in the main city square (Loggia). Some were found in the gardens of monasteries or transferred from nearby villages to the estates of the noblemen, while others were lost in the process, so only drawings exist. After Mommsen and Kandler wrote down the inscriptions, most of them were taken to the atrium of gymnasium and after I9II in the Museum of Koper, where they today stand inserted in the wall.

\footnotetext{
Alka Starac, "Pitanje istočne granice Cisalpinske Galije i odnos općina Tergeste i Egida", Histria Archaeologica 24-25 (1993-1994), 24-29.

Degrassi, Abitati Preistorici E Romani, 798; Šašel, “Koper”, 446.
} 


\section{Onomastical analysis of the inscriptions}

\section{Votive inscription dedicated to Isis}

This monument (Inscr. It. X. 3. I; CIL V 484) is a votive ara, made in Aurisina limestone (height: 0,96 m, width: $0,33 \mathrm{~m}$, thickness: $0,34 \mathrm{~m}$ ). The inscription is found within a rectangular inscription field, which is framed by a triple moulded belt on the front and the right side. The part of the upper frame was cut off. The ara was found in the episcopal palace and is now kept in the Museo Lapidario Maffeiano in Verona. The inscription reads:

\section{Isidi \\ sacrum \\ exmonit(u) \\ eius d(ono) d(edit) \\ L(ucius) Valerius \\ Memor \\ VI vir Augustalis \\ l(ocus) d(atus) p(ublice) \\ "Dedicated to Isis upon her ad monition, as a gift by Lucius Valerius Memor, member of a board of six priests of Augustus, place given by the comminunity}

This is a monument dedicated to the Egyptian goddess Isis by Lucius Valerius Memor, who also served as a priest of Augustus.

Tria nomina formula in which the name of the deceased is written is a sign that he had Roman citizenship.

Praenomen Lucius is one of the most common Roman names.

Nomen gentile Valerius is also very common and found all over the Empire. ${ }^{I I}$ The name comes

According to C. Tititus Probus in his De praenomibus 3.I., Varo thought that there were about thirty praenomina, but already during the Late Republican and Early Imperial times, only seventeen were used. These were: A(ulus); Ap(pius); C(aius); $\mathrm{Cn}$ (aeus); D(ecimus); L(ucius); M(arcus); Man(ius); N(umerius); P(ublius); Q(uintus); Ser-vius); Sex(tius); Sp(urius); Tib(erius); T(itus); V(ibius). Matijašić also adds K(aeso) to this list (Robert Matijašić, Uvod u latinsku epigrafiju (Pula: Filozofski fakultet u Puli, 2002), 59).

II Andras Mócsy, Nomenclator provinciarum Europae Latinarum et Galliae Cisalpinae: cum indice inverso (Budapest: Népművelési Propaganda Iroda, 1983), 300; Barnabas Lórincz, Onomasticon provinci- from Latin and was very popular in northern Italy and the East, especially during the late antiquity. It rose to popularity during the Tetrarchy and it is considered to be an imperial gentilitium, related to emperor Diocletian.

Cognomen Memor is less frequent and considered to be of Latin origin. ${ }^{13}$ It is found on total of twenty two inscriptions across the western provinces and Italy. The highest number of inscriptions which mention this name are from Italy, with the provinces Gallia Belgica and Pannonia also having some recordings of this cognomen. The rest of the inscriptions are spread across the other western provinces: Hispania, Gallia Narbonennsis, Dalmatia, Gallia Lugdunensis, Britannia and Moesia Inferior. ${ }^{14}$

Lucius Valerius Memor also recorded that he was a member of an imperial cult and held an office as one of the seviri Augustales. These priests were often freedmen who sought to improve their social status through religious functions. Their duty was to take care of the imperial cult of Augustus, but also of later emperors. They also had an obligation to fund public works, pay summa honoraria or organize games. ${ }^{15}$ This individual was likely a significant benefactor who was honoured after his death by being given a special funerary spot.

Due to his service as a priest of imperial cult and his Roman name, the deceased was almost certainly a freedman whose origin was probably somewhere in the West, where the Romanization has already taken place.

arum Europae Latinarum, vol. IV: QVADRATIA-ZVRES (Wien: Forschunsgesellschaft Wiener Stadtarchäologie, 2002); 143-146.

I2 Bennet Salway, "What's in a Name? A Survey of Roman Onomastic Practice from c. 700 B.C. to A.D. 700 ." Journal of Roman Studies 84 (1994), 124-145.

13 Alföldy, Die Personennamen in der Römischen Provinz Dalmatia, 340.

I4 Iiro Kajanto, The Latin Cognomina: Societas Scientiarum Fennica, Commentationes Humanarum Litterarum, XXXVI 2 (Helsinki, 1965), 255; Mócsy, Nomenclator provinciarum Europae Latinarum et Galliae Cisalpinae, 185; Lörincz, Onomasticon provinciarum Europae Latinarum, vol. IV, $75-76$.

I5 Lawrence J. F. Keppie, Understanding Roman Inscriptions (Baltimore: Johns Hopkins University Press, 1991), 57-58; Lily Ross Taylor, "Augustales, Seviri Augustales, and Seviri: A Chronological Study." Transactions and Proceedings of the American Philological Association (1914), 232. 
Date of this monument is difficult to assert on the basis of epigraphical features. It can be conjectured that the monument was erected in the 2nd century AD as the term seviri Augustalis became the most frequently used. ${ }^{16}$

\section{Votive inscription dedicated to Silvanus}

This monument is a votive inscription dedicated to Silvanus (Inscr. It. X. 3. 2; CIL V 485). It is engraved in a small stone slab, which supposedly stood inserted in the city walls. Mommsen, on the other hand, saw it on a public square (Loggia). Now it cannot be found anymore. The inscription reads:

\section{Silvano

This monument is a votive inscription dedicated to Silvanus, a popular deity of the woods.

The abbreviation at the end of the inscription $(V S L M)$ indicates that it is a monument erected after a successful completion of some kind of business venture, trip or a vow taken earlier. ${ }^{17}$ Altars of this kind are very common across the whole Empire.

The name of the dedicator, Quintus Appuleius Epagathus, is written as tria nomina, which means that the individual had Roman citizenship.

Praenomen Quintus is one of the most common Roman names.

His nomen gentile, Appuleius, originates from gens Appulea, an old Roman plebeian family). ${ }^{18}$ It was very popular in Italy. ${ }^{19}$

16 Ross Taylor, "Augustales, Seviri Augustales, and Seviri: A Chronological Study", 240.

17 Keppie, Understanding Roman Inscriptions, 93.

I8 William Smith, William Wayte, ed., A Dictionary Of Greek and Roman Antiquities (London: John Murray, 1890), 248.

19 Alföldy, Die Personennamen in der Römischen Provinz Dalmatia, 60.
His cognomen, Epagathus, is rather rare and of Greek origin. ${ }^{20}$

It appears on eighteen inscriptions, mostly from Italy and the western provinces like Hispania, ${ }^{21}$ Dalmatia, ${ }^{22}$ Gallia Narbonensis and Moesia Inferior. $^{23}$

Quintus Appuleius Epagathus was most likely a slave, whose name is of oriental, Greek origin. After some time he acquired freedom and citizenship, likely by way of manumission. In this way his praenomen and nomen gentile were inherited from his former master, while he retained his single slave name, Epagathus, as a cognomen. While his origin might have been from the East, a Greek name is not sufficient to make this claim, since slaves were often given Greek names regardless of their origin, especially after the Late Republic and Early Empire periods. ${ }^{24}$ However, since the master bears a true Roman name of Italic origin, it can be pressumed certain Quintus Appuleius was a natural-born citizen, who was maybe a colonist from Italy and owned land in Aegida.

The monument is dated to $\mathrm{I}^{\text {st }}$ and 2 nd cen tury AD.

\section{Funerary monument which mentions an individual of the Pupinia tribe}

This monument (Inscr. It. X. 3. 6; CIL V 487) has a cuboid shape and is made in Aurisina limestone (height: 0,29 m, width: $0,86 \mathrm{~m}$, thickness: 0,12 m). Letters are finely inscribed and deep-cut. It first stood in the wall of Episcopal palace. Mommsen and Kandler saw it built into the floor on the entrance of the local school or nursery while others saw it in the atrium of the gymnasium. Now it is kept in the Museum of Koper. The first line of inscription is lost, but Tomasini and Gravisi transcribed it. The inscription reads:

\footnotetext{
20 Alföldy, Die Personennamen in der Römischen Provinz Dalmatia, 360

2 I Epacathus(!) - CIL II 5527

$22\{$ A\}epacathus (!) - CIL III 3175 b

23 Mócsy, Nomenclator provinciarum Europae Latinarum et Galliae Cisalpinae, 114; Lőrincz, Onomasticon provinciarum Europae Latinarum, vol. II, 118 .

24 Matijašić, Uvod u latinsku epigrafiju, 62.
} 
---]Pup(inia) Forens[is]

[annor] um XXIII

[lec]tus ordine iura[torum sentetia]

"Pupinia of the Forensis, years 23, chosen by the decision of the order of jurors"

This inscription mentions only one person whose name is not fully preserved. Praenomen and nomen gentile are completely missing, but the tribal affiliation, cognomen and age are preserved.

It is certain that Pup(inia) refers to the tribe in which the person was enrolled, as it is one of thirty-five known Roman tribes. ${ }^{25}$ As mentioned in the introduction, citizens of Tergeste were enrolled in the same tribe. Likely, when Aegida was constituted as a municpium, its inhabitants were also assigned to the tribe Pupinia . ${ }^{26}$

Cognomen Forensis is very rare and there is only one other inscription mentioning this surname in the western provinces ${ }^{27}$. Its origin is Latin and the word itself derives from the word for forum so it can be considered a true Roman cognomen. ${ }^{28}$

The last row of the inscription mentions a political function or an appointment. The formula lectus ordine iuratorum sentetia means that this person was elected for some magistracy. Two other inscriptions from Koper (Inscr. It. X. 3. 7.) and Aquileia (CIL V 949) also uses the same formula. There are different views on what this appointment might be related to. One is that this magistracy was a form of a legal advisor in the communities. There is also an argument that the formula itself signifies a different magistracy, that of an advisor to censor who would be elected by the decurions. Lastly, one theory suggests that it might signify a person elected into municpial ordo decurionum during the census. ${ }^{29}$ In any case, it is likely that be-

Keppie, Understanding Roman Inscriptions, I40; Matijasici, Uvod u latinsku epigrafiju, 66.

26 Starac, "Pitanje istočne granice Cisalpinske Galije i odnos općina Tergeste i Egida", 28-29.

27 Foresis-CIL III 1968; Mócsy, Nomenclator provinciarum Europae Latinarum et Galliae Cisalpinae, 129; Lórincz, Onomasticon provinciarum Europae Latinarum, vol. II, 148.

28 Kajanto, The Latin Cognomina, 208; Alföldy, Die Personennamen in der Römischen Provinz Dalmatia, 340 .

29 Degrassi, Abitati Preistorici, 802-803; Alka Starac, "Pitanje istočne granice Cisalpinske Galije i odnos općina Tergeste i Egida”, 26. cause this individual was appointed to some magistratcy, he was a Roman citizen.

Be that as it may, this formula appears only in two other inscriptions in northern Italy and Istria and it is possible that it was used only in a rather short time of period and small geographical area. ${ }^{30}$ The inscription is considered to have been made in the early $\mathrm{s}^{\mathrm{st}}$ century $\mathrm{AD}$.

\section{Funerary monument \\ of Lucius Publicius Syntropus}

This big stone monument was used as a support for the door frame of the doors on the southern entrance of the Koper cathedral (Inscr. It. X. 3. 6; CIL V 488). The monument, together with the doors is situated in the street close to the public square. The monument went missing after 1788 . The inscription reads:

\section{L(ucius) Publicius \\ Syntropus \\ archigallus \\ $v$ (ivus) f(ecit) sibi et \\ [...] \\ $h(o c) m$ (onumentum) $b($ eredem) $n($ on) s(equ- \\ itur) \\ "Lucius Publicius Syntropus, archigallus. made it for himself while still alive. This mo- nument does not follow the heir}

This is a monument of funerary character, erected by Lucius Publicius Syntropus for himself and one other person whose name is not preserved because the fifth row of the inscription is missing.

Tria nomina formula, in which the name is written, is a sign of Roman citizenship.

Praenomen Lucius is one of the most common Roman names.

Nomen gentile, Publicius, is attested very often in the northern Italy, especially in the area around Tergeste, northern Istria and Cisalpine Gaul.

30 Maria S. Rossignano, "I Praefecti iure dicundo nell'Italia settentrionale" in Epigrafia. Actes du colloque international d'épigraphie latine en mémoire de Attilio Degrassi pour le centenaire de sa naissance. Actes de colloque de Rome (27-28 mai 1988) (Rome: École Française de Rome, 1991), 520. 
It was associated with municipal freedmen of oriental or African origin after the Constitutio Antoninana was enacted. ${ }^{3 \mathrm{I}}$ The name originally comes from Latin. ${ }^{32}$

Cognomen Syntropus is considered to be of oriental origin and popular among freedmen. ${ }^{33}$

Lucius Publicius Syntropus also held a function of an archigallus, a high official of the cult of Magna Mater. Galli were priests of the said goddess who originated in Asia Minor during the Hellenistic period. There are conflicting views among authors as to when the institution of archigalli first appeared. Some claim it was during the reign of Claudius, while other put it in the 2 nd century $\mathrm{AD}$, after the reforms of Antoninus Pius. ${ }^{34}$ In the eastern provinces they held some civil magistracies, while in the West their function was reserved for religion and rituals in which they often participated with other priests. Archigalli were mostly present in the cities with the status of colonies, but also in some smaller settlements. ${ }^{35}$ They are mentioned by Pliny (HN. 35. 7.), but most of the information comes from epigraphic sources which number twenty-five inscriptions. They reveal that archigalli were often freedmen of oriental origin. ${ }^{36}$

From the analysis of the inscription, the name and the function mentioned, it can be concluded that Lucius Publicius Syntropus was a freedman. He was likely of oriental or African origin and held a function of archigallus, the priest of the cult of Magna Mater. It is unknown where he performed his function, but Tergeste, where three in-

31 Alföldy, Die Personennamen in der Römischen Provinz Dalmatia, 112; Palma Karkovic Takalic, "Period of Introduction and Role of Archigalli in Context of the Inscription of L. Publicius Syntropus from Koper "Archaeologia Adriatica 6 (2012): 89 and 94 .

32 Alföldy, Die Personennamen in der Römischen Provinz Dalmatia, 337.

33 Alföldy, Die Personennamen in der Römischen Provinz Dalmatia, 304.

34 For the earlier datation see Jacopo Carcopino, Aspect mystiques de la Rome païenne (Paris: L'Artisan du Livre, 1942); for the later datation see J. Beaujeu, La religion romaine à l'époque de l'empire, La politique religieuse des Antonins (96-192) (Paris: Les Belles-Lettres, 1955); P. Lambrechts, R. Bogaert, Asclépios, archigalle pessinontien de Cybèle. Hommages à Marcel Renard, II., Coll. Latomus io2, (1969).

35 Karković Takalić, "Period of Introduction and Role of Archigalli",9698.

36 Karković Takalić, "Period of Introduction and Role of Archigalli", 94. scriptions mentioning Magna Mater were found, ${ }^{3}$ and Aquileia, the great trade port and Regio $X$ capital, are viable candidates.

The monument was dated in the time frame from second half of $\mathrm{I}^{\text {st }}$ century to first half of 2 nd century AD. The date is based on the use of $\mathrm{v}(\mathrm{i}$ vus) $f($ ecit) sibi formula which is often found in wider Trieste area during the second half of $\mathrm{I}^{\text {st }}$ century $\mathrm{AD}$. The lack of $\mathrm{D}$ (is) $\mathrm{M}$ (anibus) abbreviation, which appeared in the middle of the $\mathrm{I}^{\text {st }}$ century $\mathrm{AD}$, and became common from 2 nd century $\mathrm{AD}$ onwards, indicates a bit earlier date, towards the middle of the $\mathrm{I}^{\text {st }}$ century AD. ${ }^{3}$

\section{Public inscription of Sextius Brinniarius Certus}

The monument (Inscr. It. X. 3. 6; CIL V 489) is engraved in the Aurisina limestone slab, without a frame (height: $0,5 \mathrm{I} \mathrm{m}$, width: I,02 $\mathrm{m}$, thickness: $0,14 \mathrm{~m}$ ). It is deformed by four holes drilled in recent time. The letters are finely inscribed and deep-cut. The inscription protruded from a window shaft in the Episcopal palace. Kandler and Mommsen collected it and first put it on the public square. Afterwards, it came to the atrium of the gymnasium; since I9I the slab has been kept in the Museum of Koper. The inscription reads:

Sex(tius) Brinniarius
Certus
voto compospecun[ia]
suaportic(um) fecit lon (gam) p(edes) C
"Sextius Brinniarius Certus, having his wish
fulfilled made this portico too feet long at
his own expense"

(

(

This monument is of public character with an inscription that mentions a benefactor, Sextius Brinniarius Certus, who was wealthy enough to erect a portico with his own funds.

Tria nomina formula in which the name is written, suggests that he had Roman citizenship.

His praenomen, Sextius, is one of the 18 most common Roman names.

\footnotetext{
$37 \quad \mathrm{CILV}_{518}, \mathrm{CILV}_{519}, \mathrm{CILV}_{520}$

38 Karković Takalić, "Period of Introduction and Role of Archigalli", I00.
} 
Nomen gentile, Brinniarius, is of unknown origin and this inscription is the only instance where it is mentioned. It is possible that this is a pseudogentilitium, which originated from a fathers name as a product of acceptance of Roman nomenclature. The suffix -ius can also be a proof of this assumption. This custom was very popular in the Celtic areas. ${ }^{39}$

Cognomen Certus is considered a common Latin cognomen. ${ }^{4}$ It is found on thirty-six inscriptions in total across the western provinces and Italy. Provinces which contain the majority of these inscriptions are Dalmatia ${ }^{41}$ and Gallia Narbonensis. Others are mostly found in northern Italy and a less significant number in other provinces. ${ }^{42}$ This cognomen was very popular in Italy and the West. ${ }^{43}$ It is an example of giving nicknames based on the quality a person can possess. This practice was very common in Roman nomenclature and in this case it is an adjective which can be translated as "reliable".

His cognomen, which is relatively often found in western provinces and is of simple Latin origin, might indicate that Sextius Brinniarius Certus originated from somewhere in the West.

The monument is dated in the $\mathrm{I}^{\text {st }}$ century BC and early $\mathrm{I}^{\text {st }}$ century AD.

Funerary monument to Publius Aelius Victor A small altar (arula) (Inscr. It. X. 3. 7; CIL V 492) made in limestone from a local quarry near Koper (height: $0,62 \mathrm{~m}$, width: $0,45 \mathrm{~m}$, thickness: 0,30 $\mathrm{m})$. Letters are not carefully engraved and the back side is rough. It stood near the church of St. Nicholas in Koper. Later it was in possession of Petronio family; Kandler and Mommsen saw and processed

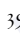

39

Fulvia Mainardis, E ora sono tutti Romani. L'evoluzione delle formule onomastiche nelle iscrizioni della Transpadanaromana (Roma, La Sapienza, 1997), 94.

40 Alföldy, Die Personennamen in der Römischen Provinz Dalmatia, 340.

Form Cirtus(!) - CIL III 13292

42 Mócsy, Nomenclator provinciarum Europae Latinarum et Galliae Cisalpinae, 75; Lőrincz, Onomasticon provinciarum Europae Latinarum, vol. II, , si; Ljubica Perinić, "O zavjetnom natpisu Minervi "Opuscula Archaeologica 23-24 (2000), 5 .

43 Alföldy, Die Personennamen in der Römischen Provinz Dalmatia, 170.

44 Kajanto, The Latin Cognomina, 34. it in their palace. It was then transferred to atrium of the gymnasium and since I9I it has been kept in the Museum of Koper. The inscription reads:

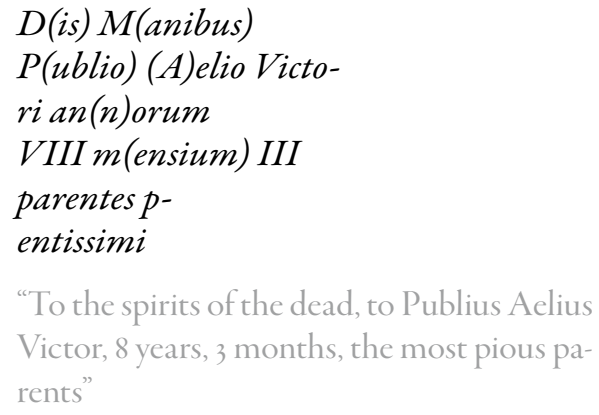

This is a funerary monument erected by the parents for their son who died young.

Tria nomina formula in which his name is written, suggests that the deceased had Roman citizenship, which he certainly obtained by birth.

His praenomen, Publius, is one of the $\mathrm{I} 8$ most common Roman names.

Nomen gentile, Aelius, is undoubtedly of Latin origin. ${ }^{45}$ It is very useful for dating, since it can be associated with emperor Hadrian, who was a member of gens Aelia. During the second century $\mathrm{AD}$ it became widespread across the Empire as Hadrian gave citizenship and established colonies in different provinces. This practice continued with Antoninus Pius who was adopted as a successor and retained the family name. ${ }^{46}$

Cognomen Victor is a very popular Roman surname of Latin origin. ${ }^{47}$ It was also very popular surname in all provinces, especially those in the West and on the frontier. Gallia Belgica, Pannonia and Italy are the regions where over one hundred fifty inscriptions with this surname come from. ${ }^{48}$ It is likely that the name was given as a "wish name" ${ }^{\prime 99}$ by parents in hope for a child to develop cer-

Alföldy, Die Personennamen in der Römischen Provinz Dalmatia, 335 .

46 Smith, A Dictionary Of Greek And Roman Antiquities, 27-28; Keppie, Understanding Roman Inscriptions, 28.

47 Alföldy, Die Personennamen in der Römischen Provinz Dalmatia, 326 and 34 I.

48 Mócsy, Nomenclator provinciarum Europae Latinarum et Galliae Cisalpinae, 311; Lörincz, Onomasticon provinciarum Europae Latinarum, vol. IV, 167-168

49 
tain qualities during life, which was a very common Roman practice. ${ }^{5}$

The name of Publius Aelius Victor suggests that he was a Roman citizen. He obtained Roman citizenship by birth. Nomen gentile Aelius was granted to his parents during or sometime after the rule of emperor Hadrian. Together with it and the use of the abbreviation DM, the inscription can be dated to the 2 nd century AD or later.

\section{Funerary monument to Publius Aelius Victor}

The exact origin of this monument is unknown, but it is thought to come from Koper (Inscr. It. X. 3. 8; $C I L \mathrm{~V}$ 493). The inscription reads:

\section{$D$ (is) M(anibus) \\ $P($ ublio) (A)elio Victori \\ annor(um) VIm(ensium) VIIId(ierum)IIII \\ P(ublius) (A)elius Quart(us) et \\ Sal L(uci)f(ilia) Nicostrat(a) \\ parentes pientissi(mi) \\ "To the spirits of the dead, to Publius Aelius \\ Victor, 6 years, 8 months, 4 days, Publius Ae- \\ lius Quartus, and Sal Nicostrata, daughter \\ of Lucius, the most pious parents"}

This funerary monument mentions three people in total: the deceased boy Publius Aelius Victor and his parents, Publius Aelius Quartus and Sal Nicostrata.

Publius Aelius Victor, the person for whom the monument is erected, was a Roman citizen, likely by birth, because the tria nomina formula is used. He could have been a relative of the Publius Aelius Victor mentioned in the previous inscription.

Hispraenomen, Publius, is one of thei 8 most common Roman names.

Nomen gentile Aelius, like in previous example, is related to Roman family name of which emperor Hadrian was the most famous member, gens Aelia. It indicates that his parents or further ancestors received citizenship during or after the rule of Hadrian.

50 Kajanto, The Latin Cognomina, 57 and 72
Victor is a very frequent cognomen found often across the Empire. ${ }^{51}$

The inscription also mentions the father of the deceased boy, whose name is Publius Aelius Quartus.

Considering his nomen gentile, Publius Aelius Quartus lived or received his citizenship during or after the rule of emperor Hadrian. It is also possible that his ancestors received the citizenship and he obtained it by birth.

Cognomen Quartus is often found among Romans and it certainly comes from Latin. ${ }^{52}$ Its origin is probably from a common Roman practice of giving nicknames to children in big families, e.g. Primus, Secundus, Tertius or Tertia etc. for females. ${ }^{53}$ However, this cognomen is found in significant numbers across the western Roman provinces, especially in the places where the Celtic population lived. The regions with highest number of inscriptions which mention this name are Noricum, northern Italy and Gallia Narbonensis. ${ }^{54}$ This might indicate a former peregrine status and maybe a Celtic origin of $\mathrm{Pu}-$ blius Aelius Quartus, but this is hard to prove.

The only things certain are that before the rule of Hadrian, he or his ancestors were not citizens, therefore they must've been peregrines or slaves. The most likely posibility is that Publius Aelius Quartus was a descendant of or a person himself who received the citizenship. Due to popularity of his cognomen in the Celtic areas, it is possible that he was named Quartus and kept this name after the conferral of citizenship or as a descendant he received the name which was already familiar among both Romans and Celts. The most likely posibility is then that he or the ancestors of Publius Aelius Quartus received citizenship as peregrines and then immigrated to Aegida during the 2nd century AD.

\footnotetext{
5I Alföldy, Die Personennamen in der Römischen Provinz Dalmatia, 326 and $34 \mathrm{I}$.

52 Alföldy, Die Personennamen in der Römischen Provinz Dalmatia, 341.

53 Matijašić, Uvod u latinsku epigrafiju, 61-62.

54 Alföldy, Die Personennamen in der Römischen Provinz Dalmatia, 278; Mócsy, Nomenclator provinciarum Europae Latinarum et Galliae Cisalpinae, 238; Lörincz, Onomasticon provinciarum Europae Latinarum, vol. IV, 167-168.
} 
Last person mentioned in this inscription is the mother of the deceased and the wife of $\mathrm{Pu}$ blius Aelius Quartus. She is Sal Nicostrata, daughter of Lucius. Although her nomen gentile (perhaps it was Salvia, as suggested in the database entry) $)^{55}$ can only be guessed, her cognomen is clearly of oriental, Greek origin. ${ }^{56}$

Since nomen gentile, cognomen and filiation are part of her name, she was certainly a Roman citizen. However, her cognomen reveals that she was probably a freed slave or a daughter of a freed slave as marriage could not have been legal if she was not a citizen.

Like in the previous inscription, nomen gentile Aelius, which was granted to the parents of the deceased or their ancestors during or sometime after the rule of emperor Hadrian, helps to date this monument. Combined with the use of the abbreviation $\mathrm{DM}$, the datation can be from 2 nd century $\mathrm{AD}$ onwards.

\section{Funerary monument of Titus Pistor, Flaminia and Maesia}

This monument is a cippus (Inscr. It. X. 3. I3), made in Aurisina limestone (height: $0,50 \mathrm{~m}$, width $0,24 \mathrm{~m}$, thickness: $0,20 \mathrm{~m}$ ). The upper, lower and right side is diminished. Lines of the letters are small and worn out. The place of finding is not known. The monument stood in the atrium of praetorial palace, then in the atrium of curia and gymnasium. Finally, in I9II, it was stored in the Museum of Koper. The inscription reads:

$$
\begin{aligned}
& \text { T. (vel P.) Ag[---] } \\
& \text { Pisto[r] v(ivus) f(ecit) [s(ibi) } \\
& \text { et] Flamini[iae --- uxori?) } \\
& \text { e]t Maes[iae --- et---] } \\
& \text { ni[---] } \\
& \text { hoc mon(umentum) [heredem non seque- } \\
& \text { tur] }
\end{aligned}
$$

\footnotetext{
55 EDRoo7638; EDCS-04200580 reconstructs the second parents name as Sal(vius) Nicostrat(us) which would make both parents males and this is almost certainly a wrong assumption.

56 Alföldy, Die Personennamen in der Römischen Provinz Dalmatia, 361.
}

\section{Titus Pistor, made it for himself while still alive, and to (wife) Flaminia, and to Maesia, this monument does not follow the heir"}

This severely damaged funerary monument mentions three persons in total. The relationship between them cannot be known with certainty.

The male person is mentioned first, Titus Pistor. While his nomen gentile is not fully preserved, its presence indicates that he was a Roman citizen.

Praenomen Titus is a very frequent Roman name.

In contrast, cognomen Pistor is mentioned only on this monument in the western provinces and Italy. It comes from Latin and likely derives from a word for an artisan. ${ }^{57}$ Giving nicknames based on occupation or profession was very common in Roman nomenclature and can be a sign of a former slave status ..$^{8}$

The second person mentioned in the inscription a female whose name is Flaminia. It is probably a nomen gentile originating from gens Flaminia, a Roman plebeian family. ${ }^{59}$

Cognomen, which would tell more about Italic or perhaps slave origin of Flaminia is not preserved, so nothing more can be told except that in the reconstruction of the inscription it is presumed that she is the wife of Titus Pistor.

Last person mentioned in the inscription is a female named Maesia. This name was very common in Italy. Its origin is Latin and it was very popular. $^{60}$

Due to the lack of use of DM abbreviation the monument can be dated in first half of the $\mathrm{I}^{\text {st }}$ century AD.

\footnotetext{
From Latin pistor, -oris, m. miller, bread-maker, baker

Kajanto, The Latin Cognomina, 322.

Smith, A Dictionary Of Greek And Roman Antiquities, I6I.

This is true for the form Maesius, since feminine form is rare, with only 7 inscriptions mentioning it; Alföldy, Die Personennamen in der Römischen Provinz Dalmatia, 337; Mócsy, Nomenclator provinciarum Europae Latinarum et Galliae Cisalpinae, 173; Barnabas Lörincz, Onomasticon provinciarum Europae Latinarum, vol. III: LABAREVS-PYTHEA (Wien: Forschunsgesellschaft Wiener Stadtarchäologie, 2000), 45
} 


\section{Funerary monument of Baburia Plotia}

This monument (Inscr. It. X. 3. I 4) was a stone box which was inscribed on the lateral side. An image was decorated on both sides where single handles stood. It supposedly stood on the gates which were called Piazzale di Porta Ognissanti (The Square of All Saints). The inscription reads:

\section{$D$ (is) $M$ (anibus)}

Baburiae Plotiae

Taronii Plotianus et Iuliane

matripientissimae

\section{"To the spirits of the dead, to Baburia Plotia, \\ Taronians Plotianus and Iuliane to the most pious mother"}

This funerary monument mentions three people from the same family.

The deceased, Baburia Plotia has a usual naming formula for women, which consists of a nomen gentile and a cognomen. This indicates that Baburia Plotia was a Roman citizen.

Her nomen gentile, Baburia is known only from Italy, so it can be considered to be of Latin origin. ${ }^{61}$ Same can be concluded for cognomen Plotia, which derives from the masculine form Plotius, which is also considered to be of Latin origin and very popular among Romans. ${ }^{62}$

Second person mentioned in the inscription is the apparent son of Baburia Plotia, Plotianus.

His name also seems to be of Latin origin, the more common form being Plotius, which was very popular in Italy, Hispania and Dalmatia, ${ }^{63}$ while Plotianus is mentioned only three times in the western provinces and Italy.

Third person mentioned is Iuliane, who is supposed to be the daughter of the deceased. Her name is also Roman and can be considered to be of

61 Mócsy, Nomenclator provinciarum Europae Latinarum et Galliae Cisalpinae, 42; Barnabas Lörincz, Ferenc Redö, Onomasticon provinciarum Europae latinarum, vol. I: Aba-Bysanus (Budapest: Archaeolingua Alapítvány, 1994), 268.

62 Alföldy, Die Personennamen in der Römischen Provinz Dalmatia, 337.

63 Lỏrincz, Onomasticon provinciarum Europae Latinarum, vol. III, 226.

64 Lỏrincz, Onomasticon provinciarum Europae Latinarum, vol. IV, 147.
Latin origin, deriving from gens Iulia. It is possible that the name Iuliane was misspelled by the engraver, since it doesn't fit in any Latin case.

The most interesting part of the inscription is the nomen gentile Taronius in the plural nominative case, which relates to Plotianus and Iuliane. The name itself seems to be quite rare ${ }^{65}$ and is limited to Italy. It is interesting to point out that five inscriptions, i.e. majority of them come from Amiternum or its vicinity, ${ }^{66}$ so there is a possibility that the name might be of ancient Sabine origin.

From te analysis of the names mentioned in the inscriptions, it is likely that it reffers to the family of Roman citizens, who all bear Roman names, Its is possible therefore that they were of Italic origin and immigrated to Aegida, maybe from central Italy.

The monument is dated to period from the beginning of the $2^{\text {nd }}$ century onwards.

\section{Funerary monument to Gaius Calpurnius Alexsa}

This monument (Inscr. It. X. 3. I $4 ;$ CIL V 495) is a plate without a frame, made in Grisignian (today Grožnjan in Croatia) limestone, broken in two pieces (height: $0,44 \mathrm{~m}$, width: $0,57 \mathrm{~m}$ ). Letters are finely inscribed and deep-cut. Kandler and Mommsen wrote the inscription down while it stood on the public square (Loggia), from where it was placed in the atrium of the gymnaisum. Since I9II, it has been inserted into the wall of the Koper museum. The inscription reads:

C(aius) Calpurnius

C(ai) Frugi l(ibertus)

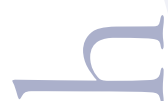

Alexsa

Sabinnaeus

filius patri

de suo

peculio fecit

Lőrincz, Onomasticon provinciarum Europae Latinarum, vol. IV, 226.

66 CIL I 3292, CIL IX 4302, AE 1992, 0484, AE 1992, 0486, AE i992, 0487 . 
Gaius Calpurnius Alexsa, freedman of Ga-

ius Frugi, son Sabinnaeus erected (this monument) to his father at his own expense"

This is a funerary monument which mentions a liberated slave Gaius Calpurnius Alexsa, his former master Gaius Calpurnius Frugi and his son Sabinnaeus.

After manumission of Gaius Calpurnius Alexsa, praenomen and nomen gentile of his former master became a part of his new Roman name, as it was common Roman practice. ${ }^{67}$

Nomen gentile Calpurnius was a very common Roman name, especially among the senatorial class. This nomen gentile was very popular in Liburnia and western Istria, ${ }^{68}$ but also in Italy and Hispania, where over one hundred and thirty inscriptions with this name were found. Its origin is from gens Calpurnia, which rose to prominence after the Punic Wars. Many members of this gens became consuls. ${ }^{69}$

His single slave name, Alexsa, became cognomen, which was a common practice for that social class. ${ }^{7}$ Alexsa is likely of oriental, Greek origin and is attested in only one other inscription in the western provinces. ${ }^{71}$ Entry in the database offers a possibility that form Alexsa is shortened from Alexsander. ${ }^{72}$ However, since there was enough room on the plate to inscribe the suggested full name but it was not done, probably the name Alexsa is the correct reconstruction.

Inscription in this monument also mentions the former master of the deceased. His name is Gaius Calpurnius Frugi.

His praenomen, Gaius is one of the 18 most common Roman names.

67 Salway, "What's in a Name?", I27; Matijašić, Uvod u latinsku epigrafiju, 62 .

68 Alföldy, Die Personennamen in der Römischen Provinz Dalmatia, 70.

69 Smith, A Dictionary Of Greek And Roman Antiquities, 582.

70 Matijašić, Uvod u latinsku epigrafiju, 67.

71 Lőrincz, Redő, Onomasticon provinciarum Europae Latinarum, vol. $\mathrm{I}, 74$.

72 EDCS-04200582 Epigraphik - Datenbank Clauss - Slaby. http:// www.manfredclauss.de (16.7.2015).
Nomen gentile Calpurnius, as above, was a name of very prominent family that several consuls.

Cognomen Frugi is quite rare, with only one other inscription mentioning this surname in Italy. ${ }^{73}$ The origin of the name comes from the practice of giving nicknames which denote certain quality, in this case honesty of virtuousness. ${ }^{74}$ The lack of mention of this surname in the inscriptions is contrasted by several important individuals recorded in the history that bore this surname. The most famous one is likely M. Licinius Crassus Frugi, consul in 27 AD. This particular individual, the former owner of the deceased, was related to C. Calpurnius Crassus Frugi Licianus, who lived during the rule of Nerva.

The last person mentioned in the inscription is the son of the deceased, Sabinnaeus. This monument is the only instance where this name is written in this form. ${ }^{76}$ Form Sabinus is much more common in all parts of the Empire, especially southern Italy and its origin is Latin. ${ }^{77}$ It is related to the ethnic name of the Sabines, but in this case it is probably not a sign of person's ethnicity, rather a manifestation of a practice of giving nicknames originating from the names of nations. $^{78}$

His father being a liberated slave, tria nomi$n a$ is expected to be used for Sabinnaeus. Reason for the lack of it is maybe the fact that there was no room on this plate or funds to buy a larger stone plate to inscribe everything intended.

The monument can be dated to the $\mathrm{I}^{\text {st }}$ century $\mathrm{AD}$.

3 Lỏrincz, Onomasticon provinciarum Europae Latinarum, vol III, 154; a prominent individual with this surname was M. Licinius Crassus Frugi, consul in $27 \mathrm{AD}$.

74 From the Latin frūgi adj. indecl. proper, worthy, honest, virtuous, frugal; Kajanto, The Latin Cognomina, 253 .

75 Degrassi, Inscriptiones Italiae, Vol. X., Regio X, Fasc. III, Io.

76 Mócsy, Nomenclator provinciarum Europae Latinarum et Galliae Cisalpinae, 248; Lörincz, Onomasticon provinciarum Europae Latinarum, vol. IV, 167-168.

77 Alföldy, Die Personennamen in der Römischen Provinz Dalmatia, 117 and 34I; Lörincz, Onomasticon provinciarum Europae Latinarum, vol. IV, 40 .

78 Kajanto, The Latin Cognomina, I85 


\section{Funerary monument of Quintus Cervius} Fidelis

This monument (Inscr. It. X. 3. 16; CIL V 496) is a stone plate without a frame, made in Aurisina limestone (height: $0,44 \mathrm{~m}$, width: $0,45 \mathrm{~m}$, thickness: $0,20 \mathrm{~m}$ ). It stood the house of Aurelli de Belli, near his garden. Kandler and Mommsen saw it in the public squre (Loggia), from where it came to the atrium of the gymnasium. From I9II it has been kept in the Museum of Koper. The inscription reads:

\section{Q(uintus) Cervius Q(uinti) l(ibertus) Fidelis v(ivus) f(ecit) sib(i) \\ "Quintus Cervius Fidelis, freedman of Qu- intus, made it for himself while still alive}

This monument mentions two persons: a liberated slave and his former owner.

Quintus Cervius Fidelis is mentioned to be a freedman, which means that he obtained Roman citizenship by manumission.

Praenomen and nomen gentile of his master, who is mentioned only as Quintus, became a part of his new Roman. His masters name might have been Quintus Cervius, while his cognomen is unknown.

His praenomen, Caius is one of 18 most common Roman names.

Nomen gentile Cervius likely comes from Latin..$^{79}$ It is found on fifteen inscriptions across the West, of which eight are from Italy. ${ }^{80}$

It the provinces, it signifies the population of Italic origin, as it is suggested by Alföldy in the case of Dalmatia. ${ }^{8 \mathrm{r}}$ On the other hand, at least the root of this name is related to indigenous population, especially in Istria. ${ }^{{ }_{2}}$

\footnotetext{
79 Alföldy, Die Personennamen in der Römischen Provinz Dalmatia, 336.

80 Mócsy, Nomenclator provinciarum Europae Latinarum et Galliae Cisalpinae, 76; Lőrincz, Onomasticon provinciarum Europae Latinarum, vol. II, 5 I.

8I Alföldy, Die Personennamen in der Römischen Provinz Dalmatia, 75.

82 Hans Krahe, Lexikon Altillyrischer Personennemen (Heidelberg: Carl Winter's Universitätsbuchhandlung, 1929), 28; Starac, "Pitanje istočne granice Cisalpinske Galije i odnos općina Tergeste i Egida”, 29.
}

Cognomen Fidelis is likely of Italic and certainly of Latin origin. ${ }^{83}$ This cognomen derives from the practice of naming people with nicknames which present moral and social qualities ${ }^{84}$ and was very popular among freedman. ${ }^{85}$ It is found in a relatively significant number of inscriptions, most of which are from Italy. ${ }^{86}$

From the observations and data mentioned above, it can be summarized that Quintus Cervius Fidelis was a manumitted slave. Since he was named after his owner and the cognomen is of Latin origin, nothing more can be known about Quintus Cervius Fidelis.

On the other hand, the owner and later patron of Quintus Cervius Fidelis, who bears a true Roman name and the root of the nomen gentile which is considered by authors to be of indigenous origin, is probably a descendant of indigenous Istrian population which was apparently already Romanized to some extent in the ist centruy AD.

The date when this monument was made can be asserted on the basis of one epigraphic feature. It is lack the of DM abbreviation, which was in common use by the middle of the ind century AD in this geographical area. The date can then be set to the first half of the ist century AD.

\section{Funerary monument of Caelotis Naevola}

This monument exists only as a drawing (Inscr. It. X. 3. I8; CIL V 498). It was supposedly found in Koper, but an anonymous traveller reports having seen it in the vicinity of the village St. John of Dajla, in the wall of count Grisonis's house. Count Grisoni, a nobleman from Koper, saw it fit to take it from that village and transfer it elsewhere. It was not found afterwards. The inscription reads:

\footnotetext{
83 Alföldy, Die Personennamen in der Römischen Provinz Dalmatia, 340.

84 From Latin fidelis, e, adj. trusty, trustworthy, faithful, sincere, true.

85 Kajanto, The Latin Cognomina, 203 and 254.

86 Mócsy, Nomenclator provinciarum Europae Latinarum et Galliae Cisalpinae, 126; Lörincz, Onomasticon provinciarum Europae Latinarum, vol. II, I40-141.
} 
$D(i s) M$ (anibus)

Celotis

Naevola

Mater

To the spirits of the dead, Celotis Naevola,

mother

This funerary monument mentions only one female person, the deceased Celotis Naevola. Her name is written in common onomastic formula for women, which indicates that she was a Roman citizen. Both her nomen gentile and cognomen are very rare.

Nomen gentile Celotis is attested only in this inscription.

The form Gelotis is attested in the surviving drawing of the inscription, which is also quite rare but a broad outline of the name can be discerned. It is found only in Italy and three inscriptions mention it, all in genitive case and concerning mostly former slaves. ${ }^{88}$ However, the name is also mentioned on numerous brick stamps found in Rome. They are related to Tiberius Servilius Gelos who worked for figlina Caepioniana in the beginning of the 2nd century $\mathrm{AD}^{89}$

Although it is hard to find a connection between all these inscriptions and their forms with the one from Koper, in the widest sense it can be concluded that this name and forms of this name are found among former slaves.

Cognomen Naevola is also found in only one other inscription. ${ }^{9 \circ}$ It is likely that her cognomen comes from the Latin word for mole or wart ${ }^{9 \mathrm{~T}}$ as giving nicknames for physical attributes was very common in Roman times. ${ }^{22}$

With both nomen gentile and cognomen being very rare, it is possible that this individual was

87 Mócsy, Nomenclator provinciarum Europae Latinarum et Galliae Cisalpinae, 58; Lörincz, Onomasticon provinciarum Europae Latinarum, vol. II, 18 .

88 CIL V 6808, AE 2001,576 and CIL XI 6712.

89 John P. Bodel, Roman Brick Stamps in the Kelsey Museum (Ann Arbor: University of Michigan Press, 1983), 25 .

In the masculine form Naevolus - CIL V 6447.

Lat. naevus, -i, m. mole, wart.

Kajanto, The Latin Cognomina, 245; Matijašić, Uvod u latinsku epigrafiju, 6r. of peregrine or slave status who later acquired citizenship.

The datation of this monument can be asserted on the basis of the use of DM abbreviation, which can date it in the ist AD.

\section{Funerary monument to Lucius Herennius and Lucius Priscus}

This monument is also only preserved in form of a drawing which depicts a stella with many cracks and its right side cut-off (Inscr. It. X. 3. 19; CIL $\mathrm{V}$ 499). It was supposedly found in the wall of the Episcopal garden. It is now considered lost. The inscription reads:

$$
\begin{aligned}
& \text { L(ucius) Here[nnius--] } \\
& \text { Pup(inia) i[---] } \\
& \text { v(ivus) f(ecit) s(ibi) } \\
& \text { et L(ucio) Pu[---] } \\
& \text { Prisc[co---] } \\
& \text { "Lucius Herennius, of the Pupinia tribe, } \\
& \text { made it for himself while still alive and for } \\
& \text { Lucius Pu[---] Priscus" }
\end{aligned}
$$

This monument mentions two male persons but the damage and subsequent loss of the stone plate makes the reconstruction of the names difficult.

First person mentioned is Lucius Herennius.

His praenomen, Lucius, is one of 18 most common Roman names.

Nomen gentile Herennius is very frequent in the western provinces and Italy. ${ }^{93}$ The family name comes from gens Herennia. It was a plebeian family of Samnite origin, whose members became very influential and held important political and military offices. They even entered imperial families as the wife of emperor Decius was Herennia Etruscilla. ${ }^{94}$ The name is considered to be of Latin origin..$^{5}$

\footnotetext{
93 Mócsy, Nomenclator provinciarum Europae Latinarum et Galliae Cisalpinae, 143; Lörincz, Onomasticon provinciarum Europae Latinarum, vol. II, $178-179$

94 Smith, ADictionary Of Greek And Roman Antiquities, 406-407.

95 Alföldy, Die Personennamen in der Römischen Provinz Dalmatia, 335 .
} 
The damage of the monument makes the rest of his name difficult to reconstruct. The part where the abbreviation Pup(inia) ends, a hasta which resembles letter " $I$ " is recorded on the drawing. It was ommited in the first publication of the monument and also on the proposed transliteration. Even if this hasta is not ignored as a mistake made during the drawing of the monument, the Pup(inia) part left in the inscription can be reconstructed as an affiliation to tribus Pupinia, which was one of thirty-five Roman tribes. $^{96}$

In any case, it doesn't change the fact that Lucius Herennius was likely a Roman citizen, perhaps of Italic origin.

Second person mentioned on this inscription is Lucius Priscus, also the deceased for whom the same monument was erected.

His praenomen Lucius, like in the previous case, is one of the most common ones used by Romans.

Due to damage of the monument, his nomen gentile is not entirely preserved, only the $P u$ part is visible.

His cognomen, Priscus, is certainly of Italic and Latin origin. ${ }^{97}$ In the most ancient times the name was considered Etruscan, but in the later periods became a common Roman surname. The popularity of the name is due to connection to the legendary figure of the Roman king, Tarquinius Priscus. ${ }^{98}$ It is found in large numbers across various western provinces. Most of the inscriptions with this surname come from Italy, where one hundred fifty of them are recorded. ${ }^{99}$

The datation of this monument can be set on the basis of two epigraphic features. Lack of DM abbreviation, which was in common use by the 2 nd century AD and the use VF abbreviation, which was used from middle and the end of Ist

96 Keppie, Understanding Roman Inscriptions, I40; Matijašić, Uvod u latinsku epigrafiju, 66.

97 Alföldy, Die Personennamen in der Römischen Provinz Dalmatia, 273 and 341 .

98 Kajanto, The Latin Cognomina, 7 I

99 Mócsy, Nomenclator provinciarum Europae Latinarum et Galliae Cisalpinae, 232; Lőrincz, Onomasticon provinciarum Europae Latinarum, vol. III, I62-163. century AD until the second half of 2 nd century AD the datation of the monument can be then set from the first half up to the middle of the ist century AD.

\section{Funerary monument of Gaius Lorentius Tesifon}

This monument is stone box made in Aurisina limestone (Inscr. It. X. 3. 20; CIL V 500). It is divided into three parts with numerous cracks and damages. The letters are rough and the inscription is written continuously (height: 0,65 m, width: 2,03 $\mathrm{m}$, thickness: $0, \mathrm{I} 4 \mathrm{~m}$ ). The monument stood near the Square of All Saints (Piazzale di Porta Ognissanti), from which it was later pulled down and lay near the well. Kandler and Mommsen saw it in the public square (Loggia), from where it came to atrium of the gymnasium. From I9I it has been kept in the Museum of Koper. The inscription reads:

$G$ Lorentius

Tesifon vibus

posuit sibi

"Gaius Lorentius Tesifon, placed it for him self while still alive"

The monument is of funerary character and mentions only one person, Gaius Lorentius Tesifon.

Tria nomina fromula suggests that he was a Roman citizen.

His praenomen, Lucius, is one of 18 most common Roman names.

Lorentius is a rare nomen gentile and there is only one other instance where it is recorded in this form. ${ }^{100}$ Much more frequent is Laurentius, which is certainly of Latin and Italic origin.

Cognomen Tesifon is also unique in the western provinces. It is undoubtedly of oriental origin. It is possible that this name can be related to the capital of Parthian and Sasanian Empire, Ctesiphon, which would indicate the origin more precisely. Cognomen which has a root in a geograp-

I00 Feminine form Lorentia in CIL V 1276. 
hical term was often used in Roman nomenclature, especially among former slaves. ${ }^{101}$

From these observations it can be concluded that Gaius Lorentius Tesifon was a Roman citizen who obtained citizenship probably by way of manumission. His cognomen was likely his single slave name, which is of oriental origin.

Here it is possible to make an assumption on the manner in which this individual may have end ded up in the area around Aegida during the 3 century AD. His arrival perhaps can be related to the conquest of Parthia and the sack of its capital, Ctesiphon, by emperor Septimius Severus in 197 AD. It is reported that the large number (around ten thousand, according to Cassius Dio) of slaves were captured and distributed across the Empire after this expedition ${ }^{\text {102 }}$. Although this corellation cannot be proved with utmost certainty, it is not impossible that a slave was manumitted after years of service and as a cognomen took the name of his hometown, which was destroyed and from which he was taken as a prisoner.

The datation of this monument can be asserted only on the basis of one epigraphic feature, which is the use of the formula vibus posuit. This formula was common in the Late Principate. ${ }^{103}$ The date can be therefore set to 3 rd century AD.

\section{Funerary monument of Lucida Dignitas}

This monument is a stella made of limestone (Istrian, but it is not determined which exactly), with an inscription written in finely engraved letters and in continua (Inscr. It. X. 3. 2I). The inscription field is framed by a triple moulded belt. The pediment of the stella is decorated with a rose and leaves. The stella was found in the gardens of Capuchin mon$\mathrm{ks}$, while excavating the well. It stood in the curia, after it came to the atrium of the gymnasium. From I9II, it is inserted in the wall of the Museum of Koper. The inscription reads:

\footnotetext{
IOI Kajanto, The Latin Cognomina, 45 .

102 D.C.LXXVI.9.4.

I03 Miroslav Glavičić, "Tri rimskodobna natpisa iz Senja", Senjski zbornik $23(1996), 26$
}

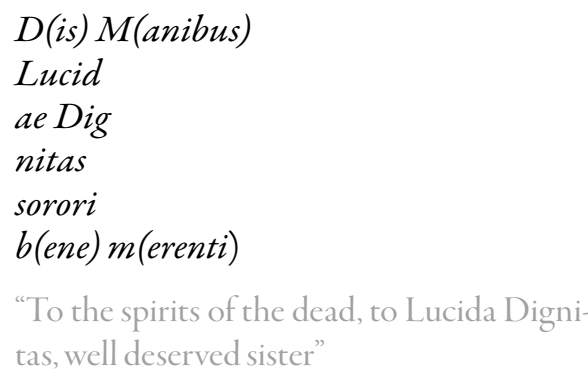

This is a funerary monument erected for $\mathrm{Lu}$ cida Dignitas. Judging by the two names which were a common onomastic practice for women, she was a Roman citizen.

Both her nomen gentile and cognomen are very rare. Lucida is only attested as a cognomen in twenty inscriptions in the western provinces and Italy. Even in other publications, Lucida from this inscription is recorded as cognomen. ${ }^{104}$

The real cognomen, Dignitas is also quite rare. There is only one other instance where the name is recorded in this form. ${ }^{105}$ Its origin is from the practice of giving names related to moral qualities of the person, in this instance the meaning being "worthy". ${ }^{106}$

While being very rare, both names are almost certainly of Latin origin. It is likely that Lucida Dignitas was a Roman citizen, maybe of Italic origin.

The use od DM abbreviation can date this monument in the ist century $\mathrm{AD}$ onwards.

\section{Funerary monument to Tullia Septimina}

A side of a stone box, made in Aurisina limestone (height: $0,55 \mathrm{~m}$, lenght: $0,55 \mathrm{~m}$, width: $0,36 \mathrm{~m}$ ). The inscription (Inscr. It. X. 3. 23; CIL V 504) is in the front and the box is decorated on both sides with two handles. It was used to store oil in the Koper drugstore. Later it changed places from curia to the atrium of the gymnasium, and in I9II it was placed in the Koper Museum. The inscription reads:

\footnotetext{
I04 Lörincz, Onomasticon provinciarum Europae Latinarum, vol. III, 35.

Ios Mócsy, Nomenclator provinciarum Europae Latinarum et Galliae Cisalpinae, 103; Lörincz, Onomasticon provinciarum Europae Latinarum, vol. II, 100

I06 From Latin dignitas, -atis, f. worth, merit, desert, character; Kajanto, The Latin Cognomina, 95 .
} 
Tulliae Septiminae

animae inocentissimae

quae vixit annis VI mens(ibus) VIIII

diebus VII Tullia Privata

mater in $(f)$ elicissima

"To Tullia Septimina, of the most innocent

soul, who lived to 6 years, 9 months, 7

days, Tullia Privata, the most unfortunate mother"

This funerary monument mentions two female persons, the deceased daughter and her mother who erected the monument.

The daughter, who died quite young, judging by the two names, was a Roman citizen by birth.

Nomen gentile Tullia belongs to one of the most ancient Roman gens, whose patrician branch was already extinct in the early Republic. The name (except for a few notable individuals, of whom Marcus Tullius Cicero is the most famous one) was common among freedmen. ${ }^{107}$

Cognomen Septimina has an origin from a common Roman practice of giving nicknames related to number of children in big families, which later became an usual cognomen.

Cognomen Privata is a frequent Roman surname of Latin origin. ${ }^{109}$ The highest number of inscriptions with this name come from Italy. ${ }^{110}$ The word itself derives from the practice of giving names originating from a certain social class.

Considering all this, both persons were Roman citizens and their Latin names might indicate that they were of Italic origin. While the mother might have been a freedman, the deceased daughter probably received citizenship by birth.

This monument can be dated on the basis of several epighrapical and onomastical features. First is the use of the form annis, which along

107 Smith, ADictionary Of Greek And Roman Antiquities, 1183.

I08 Matijašić, Uvod u latinsku epigrafiju, 6I-62.

I09 Alföldy, Die Personennamen in der Römischen Provinz Dalmatia, 34 I.

i o Mócsy, Nomenclator provinciarum Europae Latinarum et Galliae Cisalpinae, 232; Lörincz, Onomasticon provinciarum Europae Latinarum, vol. III, 165 .

I I Kajanto, The Latin Cognomina, 315 . the form annos, is common from 2 nd century AD. Secondly, the precise lifetime of the deceased being recorded on the monument, including years, months and days, became common in the 3 rd century A.D. ${ }^{\mathrm{II}}$ Datation of this monument can then be set in the 3 rd century AD.

\section{Bronze plate with inscribed names of liberated slaves}

This inscription (Inscr. It. X. 3. 30; CIL V 50I) is on a fragment of a bronze plate (height: $0,15 \mathrm{~m}$, width: $0,12 \mathrm{~m}$, thickness: $0,006-0,009 \mathrm{~m})$. It was found near Koper, in the place called Arjol, between St. Michael and the Lazaretto, on the estate of Ingaldes, a noble familiy of Koper. It is unknown how at one point the plate turned up in Vienna, but now it is kept in the Archaeological Museum of Istria, in Pula. The inscription reads:

---] Magaplina Mati (vel Matt) [---an(no rum)---, M]agaplina Tertiae lib(erta) [an(orum)--]

Magaplina Tertiae [lib]erta an(norum) [---] [Ma] gaplina Raecif(ilia) an(nnorum) LX [-Maxi]ma f(ilia) an(norum) X[--- Magaplin]us Maximaefiliae f(ilius) an (norum) [---] Magaplinus [Ma] rcellae

lib(ertus) an(norum) [---] Magaplinus [M]

arcel

lae lib(ertus) [an(norum) ---], Magaplina [Mar]cellae lib(erta) [an(norum)---

"Magaplina Mati, years

Magaplina, freedwoman of Tertia, years

Magaplina, freedwoman of Tertia, years

Magaplina, daughter of Raecus, years 60, daughter Maxima

years io, Magaplinus, son of daughter of

Maxima, years, Magaplinus, freedman of

Marcella, years, Magaplinus, freedman of

I 2 Keppie, Understanding Roman Inscriptions, 107 
Marcella, years, Magaplina, freedwoman of

Marcella, years"

This bronze plate records the names of liberated slaves, their age and names of former masters. The inscription records the family of Magaplines and their former owners. This plate is likely a legal document related to granting the Roman citizenship to people mentioned in the inscription. ${ }^{113}$

The first and most often inscribed name on this plate is Magaplinus in feminine and masculine gender. Since the plate records the names of liberated slaves, it is obvious that Magaplinus and Magaplina served as a single name before their manumission. Magaplinus is attested only in Italy as a nomen. ${ }^{114}$ The origin of the name is neither Roman nor the word comes from Latin. It's related to the name Aplis, which with its few derivatives ${ }^{115}$ was preserved in the form of Magaplinus. Different authors point out distinctly Illyrian origin due to lingustic features or Venetic due to geographical prevalence which is mainly Istria. However, all agree that it is a name of indigenous origin. ${ }^{116}$ This is further confirmed by the onomastic formula, which consists of nomen gentile (moved in the place which is usually reserved for cognomen in Roman nomenclature and filiation. This onomastical order is very characteristical for Histrian and Liburnian names.

Consideringa all this, people who bore the name Magaplinus or Magaplina mentioned on this plate, were likely the members of indigenous population living somewhere in Istria. ${ }^{118}$

Second name that can be related to indigenous population mentioned on the inscription is Raecus. Since in this inscription it appears as the

I 3 Starac, "Pitanje istočne granice Cisalpinske Galije i odnos općina Tergeste i Egida ", 3 I.

I 4 Mócsy, Nomenclator provinciarum Europae Latinarum et Galliae Cisalpinae, 173; Lörincz, Onomasticon provinciarum Europae Latinarum, vol. III, 45

I Is Other forms include: Aplo, Apludus, Aplurus, Aplus, Aplius.

I16 Krahe, Lexikon Altillyrischer Personennemen, 157; Starac, "Pitanje istočne granice Cisalpinske Galije i odnos općina Tergeste i Egida”, 30; Mate Križman, Rimska imena u Istri: osobna imena na istarskim natpisima iz rimskog doba (Zagreb: Latina Et Graeca, 1991), 200-201.

I 7 Starac, "Pitanje istočne granice Cisalpinske Galije i odnos općina Tergeste i Egida", 31 .

i 8 John J. Wilkes, The Illyrians (Cambridge: Blackwell Publishing, I992), 7 I -75 names of the parents of freedman, it is also of indigenous origin and indicates a slave past. The name is considered to be of Illyrian, but can be also considered Venetian, especially in the northern Italy. ${ }^{119}$

The names of the masters who liberated these slaves are also mentioned. They are Maxima, Marcella and Tertia. These are Roman names of Latin origin and it is not surprising that owners of these slaves are Romans, likely of Italic origin.

For the datation of this monument, only one epigraphical feature can be used. In the offered transliteration, abbreviation an is restituited as an(nnorum). If this reconstruction is accepted, then the plate can be dated to the I century AD.

\section{Funerary monument of Caius Titius}

This monument (Inscr. It. X. 3. 31; CIL V 486) is a stone plate made in limestone, with a frame made of triple moulded belt (height: $0,98 \mathrm{~m}$, width: $0,65 \mathrm{~m}$ ). It was found in 1843 , in a valley near the village of Pomjan (Italian: Paugnano), near Koper. Soon after the finding, it arrived in the Museum of Trieste, where it has been kept inserted in the wall. The inscription reads:

\section{$C$ (aius) Titius $C$ (ai)f(ilius) \\ Volt(ilia) Vienna \\ veteranus \\ leg(ionis) XV Apol(linaris) \\ "Gaius Titius, son of Gaius, Voltilia, from Vi- enne, veteran of isth legion of Apollonians"}

This is a monument of legionary veteran, who also inscribed the name of his hometown and legion in which he served.

His praenomen, Gaius is one of $\mathrm{I} 8$ most common Roman names.

His nomen gentile, Titius, is related to old but not very prominent plebeian family, gens $T i$ $t_{i a}{ }^{120}$ and is certainly of Latin origin. ${ }^{\text {. }}$

I1 Krahe, Lexikon Altillyrischer Personennemen, 97; Alföldy, Die Personennamen in der Römischen Provinz Dalmatia, 349; Križman, Rimska imena u Istri, 104.

120 Smith, A Dictionary Of Greek And Roman Antiquities, 1159 .

I21 Alföldy, Die Personennamen in der Römischen Provinz Dalmatia, 338 
This monument might seem peculiar at first because it lacks the cognomen. It was actually a common practice in the area around Aquileia and Emona for veterans to omit cognomen but to regulary include the tribe in which they were enrolled. ${ }^{\text {I22 }}$

Gaius Titius also inscribed his filiation, which reveals that his fathers name was also Gaius. His voting tribe is recorded to be Voltilia, the tribe of his hometown, Colonia Iulia Vienna Allobrogum, todays Vienne in southeastern France, south of Lyon.

From this it is easy to assert that this individual was native of Gaul, who served as a legionnaire in the isth legion of Apollonians.

This legion was raised by Octavian sometime around 40 or $4 \mathrm{I} \mathrm{BC}$. After Actium, where the legion fought, it received the title in the honor of Apollo ${ }^{123}$ and was stationed in Illyricum, the precise location being a point of debate. It is possible that it had a camp in Carnuntum near todays Vienna in Austria. The date for its occupation of Carnuntum range from Is $\mathrm{AD}$ to $50 \mathrm{AD} .^{124}$ It was previously thought that this legion had a camp in Ljubljana (Emona) ${ }^{125}$ before transfering to Carnuntum, but this hypotesis is now mostly rejected. ${ }^{126}$ In $55 \mathrm{AD}$, during the rule of Nero, the legion was transferred to the East to fight Parthians and participated in the First Jewish Revolt, but returned to Pannonia (Carnuntum) in

\footnotetext{
122 Marjeta Šašel-Kos "The isth Legion at Emona-some Thoughts", Zeitschrifffür Papyrologie und Epigraphik I09 (1995), 238.

123 E. Ritterling, "Legio" in RE XII (Stuttgart: J. B. Metzler, 1924-1925), 1747; Keppie, Understanding Roman Inscriptions, I82.

I24 Everett L. Wheeler, "Legio XV Apollinaris: From Carnuntum to Satala and beyond "in Les Légions de Rome sous le Haut-Empire, ed. Y. Le Bohec (Lyon/Paris: De Boccard, 2000), 272-273; Jerome H. Farnum, The Positioning of the Roman Imperial Legions (Oxford: Archaeopress, 2005), 23.

I25 This view became widely accepted in literature despite serious doubts being cast on it very early. Works which supported this idea include: B. Saria, "Emona als Standlager der Legio XV. Apollinaris" in Laureae Aquincenses i Diss. Pann. 2. I. (1938) 245-255; G. Alföldy, Noricum, 1974, 57; A. Mocsy, Pannonia and Upper Moesia, 74-76; J. Fitz, The Archaeology of Roman Pannonia, 1980, 143.

I26 Šašel and Weiler, "Zur augusteisch-tiberischen Inschrift von Emona", Carnuntum Jahrbuch 8 (1963-1964), 40-42; Šašl-Kos "The 15th Legion at Emona", 243.
}

71 AD. ${ }^{127}$ Save a small contribution in the conquest of Dacia (only as a vexilation), the legion stayed in Carnuntum until it was dispatched to the East sometime during the rule of Trajan never to return to Pannonia.

The fact that Gaius Titius served in a legion, and not in an auxiliary unit, indicates that he was a Roman citizen and not a peregrine who joined the army from Gaul and received citizenship upon retirement. As a veteran, Gaius Titius settled somewhere in northern Italy and Istria, similiar to other veterans of this legion, who often retired in the hintherland of Aquileia. ${ }^{\text {I2 }}$

The datation of this monument can be conjectured on the basis of the movement of the legion. During the ist century BC and AD, the legion spent the majority of its time in Illyricum and later Pannonia Superior $(55-71$ AD was spent in the East), mostly in Carnuntum. Therefore, the monument can be dated to early ist century AD.

\section{Funerary monument of Publius Acisinus}

\section{Venius and his wife Galla}

This monument (Inscr. It. X. 3.32; CIL V 49I) is a stone plate with a frame made of triple moulded belt. It was found in an unknown place near the village of Pomjan (Italian: Paugnano). With it, jars, perfume bottle and a lamp with the FORTIS stamp were found. Unfortunately, Kandler himself lost the plate in 1844 . The inscription reads:

\section{$P$ (ublius) Acisinius C(ai)f(ilius) \\ Venius \\ Galla uxor}

"Publius Acisinius Venius, son of Gaius, wife Galla"

I27 Andras Mócsy, Pannonia and Upper Moesia: A History of the Middle Danube Provinces of the Roman Empire (London/Boston: Routledge and K. Paul, 1974), 48; Wheeler, "Legio XV Apollinaris: From Carnuntum to Satala and beyond ", 260.

128 Mócsy, Pannonia and Upper Moesia, 99; Wheeler, "Legio XV Apollinaris", 260; Farnum, The Positioning of the Roman Imperial Legions, 23.

I29 Jaroslav Šašel "Zur Frühgeschichte der XV. Legion und zur Nordostgrenze der Cisalpina zur Zeit Caesars" Archäeologisch-epigraphische Studien I (1985), 547. 
This is a funerary monument which mentions two persons, husband and wife.

Tria nomina formula suggests that Publius Acisinius Venius was a Roman citizen. His filiation reveals tha he was son of Gaius.

Praenomen Publius is one of the most used Roman names.

Nomen gentile Acisinus is quite rare, this inscription being the only one containing it in Italy and the western provinces. ${ }^{130}$ Authors have suggested that it might be of Etruscan or more likely, of Illyrian origin. ${ }^{\text {. }}$

Cognomen Venius is practically unknown and is recored only as a nomen on two inscriptions. ${ }^{\text {I3 }}$

It is very hard to discern the origin of this person or its name, especially because he has a very unusual combination of non-Latin nomen gentile and cognomen, together with the filiation in genitive case, but with a common Roman name. If his nomen gentile is not of Italic origin, then it is possible that Publius was a former peregrine who obtained the citizenship later in life, despite his father having a proper Roman praenomen.

The inscription also mentions the name of the wife. There are conflicting vievs if the name inscribed is Galla or Calla. It is probably a cognomen and because of that, it is possible that the wife was a freedwoman or a peregrine whose name was not fully recorded.

This monument has only one epigraphical feature which can date it and that is the lack of DM abbreviation, which can then set the date to ist century AD.

\section{Funerary monument of Publius Sardius Prudens}

This is a stella (Inscr. It. X. 3. 33; CIL V 503) made of local limestone (height: $\mathrm{I}, 37 \mathrm{~m}$, width: 0,44

130

Mócsy, Nomenclator provinciarum Europae Latinarum et Galliae Cisalpinae, 3; Lörincz, Redö, Onomasticon provinciarum Europae Latinarum, vol. I: Aba-Bysanus, I5.

I3 I Krahe, Lexikon Altillyrischer Personennemen, i6; Križman, Rimska imena u Istri, 103.

I32 Mócsy, Nomenclator provinciarum Europae Latinarum et Galliae Cisalpinae, 305; Lőrincz, Redő, Onomasticon provinciarum Europae Latinarum, vol. I: Aba-Bysanus, 154. $\mathrm{m}$, thickness: $0,13 \mathrm{~m}$ ). The pediment is decorated with a rose inside, with single dolphins represented on the sides. It was found in the village of Monte, in the the wall of the church of St. Mary. It still stands there. The inscription reads:

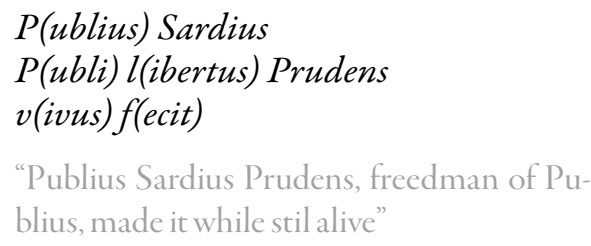

The monument records the name of citizen Publius Sardius Prudens, who obtained the citizenship by manumission and his former master, Publius.

Pranenomen Publius is one of the most often used Roman names.

Nomen gentile Sardius is quite rare, with only two inscriptions from Italy, including this one, mentioning it. ${ }^{\mathrm{I} 33}$ It is likely that upon his manumission, the former slave inherited it from his new patron. His master was probably a member of indigenous population living in Istria and northern Italy, as the root of the name is considered to be of such origin. ${ }^{\mathrm{I} 4}$

Cognomen Prudens in this form is attested on eighteen inscriptions in the western provinces and Italy $^{\mathrm{I} 35}$. However, different forms of this name, e. $\mathrm{g}$. Prudentia and Prudentius, are relativley common. Its origin is Latin and can be considered a true Roman cognomen which was given to denote a special quality a person possessed, in this case a mental qualitiy ${ }^{136}$, a common practice in Roman nomenclature. ${ }^{\mathrm{I} 37}$ It is likely that this indvidiual served his

\footnotetext{
I33 Mócsy, Nomenclator provinciarum Europae Latinarum et Galliae Cisalpinae, 253; Lörincz, Onomasticon provinciarum Europae Latinarum, vol. IV, 49 .

I34 Wilhelm Schulze, Zur Geschichte lateinischer Eigennamen (Berlin-Zürich-Dublin: Weidmann, 1966), I 13; Starac, "Pitanje istočne granice Cisalpinske Galije i odnos općina Tergeste i Egida”, 29.

I35 Mócsy, Nomenclator provinciarum Europae Latinarum et Galliae Cisalpinae, 235; Lörincz, Onomasticon provinciarum Europae Latinarum, vol. III, 169 .

I36 From the Latin prudens, -entis, adj. knowing, skilled, experienced, versed.

I37 Alföldy, Die Personennamen in der Römischen Provinz Dalmatia, 250; Kajanto, The Latin Cognomina, 34 I
} 
master well and this was in a way reflected in the cognomen which was given to him.

The monument is dated in the early $\mathrm{I}^{\text {st }}$ century AD.

\section{Monument of Sextius Pedanius Seneca}

This monument (Inscr. It. X. 3. 34) is a plinth made in sandstone (height: $0,13 \mathrm{~m}$, width: $0,25 \mathrm{~m}$, thickness: $0,12 \mathrm{~m}$ ). The right side is damaged, and the inscription is engraved with rough letters. Stones of the same shape were found in few tombs in Istria. The monument was found in wall in the field near the village of Zupanci. It was kept in the curia of Paugnano, until it came to the Museum of Koper as a gift in 1924. The inscription reads:

\section{[S]ex(tius) Pedani[us-] f(ilius) Seneca \\ Sex(tius) Pedanius, son, Seneca"}

Due to the damage of the right side of the plate filiation is not full preserved.

Pranenomen Sextius one of the most often used Roman names.

Nomen gentile Pedanius is relatively frequent, with province of Hispania being the place where it is most often used, second to it being Italy. ${ }^{138}$ It might be of Latin origin, since there are few people with the name Pedanius recorded in history, some as early as Second Punic War. ${ }^{\text {I39 }}$

Cognomen Seneca is of Latin origin. It is a cognomen which originated as a nickname denoting persons great age which was a common practice in Roman onomastics. ${ }^{140}$ Some authors hold that it might be of Celtic origin. ${ }^{14}$ This view is sometimes questioned or it is thought that the origin cannot be discerned unless the name appears in a predominately Celtic (e. g. Gaul) or Roman (e.

I3 8 Mócsy, Nomenclator provinciarum Europae Latinarum et Galliae Cisalpinae, 217; Lörincz, Onomasticon provinciarum Europae Latinarum, vol. III, I31

139 Smith, A Dictionary Of Greek And Roman Antiquities, I63.

I 40 Kajanto, The Latin Cognomina, 307.

I4I Alföldy, Die Personennamen in der Römischen Provinz Dalmatia, 293 g. Africa) area. ${ }^{142}$ It is also important to note that the names was the most popular in Hispania and then Italy. ${ }^{\mathrm{I} 3}$ Together with the nomen gentile, it is possible that this individual was from a western province, likely Hispania, where the Romanization has already taken place and the names familiar among both Romans and indigenous population were used.

There is a slight possibility that this is not a funerary monument.

The monument can be dated to late $\mathrm{I}^{\text {st }}$ century BC.

\section{A votive monument dedicated to Nemesis}

A small ara (lat. arula) made of limestone (Inscr. It. X. 3. 35). Right side is damaged (height: 0,54 $\mathrm{m}$, width: $0,25 \mathrm{~m}$, thickness: $0,25 \mathrm{~m}$ ). It was found in the village of S. Pietro dell'Amata, in the valley of Dragonja river. It was somehow brought to the Museum of Trieste by Marco Marcuzzo Villanovensi in I898. It is neither known where the monument was found nor who was the man who sold it to the Museum. It is kept in the lapidarium of the Trieste Museum. The inscription reads:
Nem[e]-
si
Aug(stae)
$\operatorname{sac}($ rum)
Qui[---]
servus L(uci)
[---]nicius
Protocteti
$[v($ otum $)] s$ (olvit) l(ibens)
"Dedicated to Nemesis the revered one,
Qui[ntus] slave of Lucius [--- nicius Proto-
ctetus, willingly and deservedly fulfilled his vow"
This is a votive monument dedicated to the goddess Nemesis, by a slave Quintus to his for-

\footnotetext{
I42 Kajanto, The Latin Cognomina, I7; Radoslav Katicic, "Zur Frage der keltischen und pannonischen Namengebiete im romischen Dalmatien", Godišnjak Centraza Balkanoloska ispitivanja IIl/I (1965), 59.

I 43 Lörincz, Onomasticon provinciarum Europae Latinarum, vol. IV, 65.
} mer master. 
Name of the dedicator is recorded only as $Q u$ intus, which was likely his single slave name. It is one of the 18 most often used Roman names.

The full name of the master for whom the monument was erected is not fully preserved with

only his praenomen and cognomen being recorded fully.

Praenomen Lucius is one of the most common Roman names.

His nomen gentile is only partially preserved and can only be guessed.

Cognomen Protoctetus is very rare and there are only three inscriptions where it is attested, two others being from Gallia Narbonensis. ${ }^{\text {I44 }}$ Entries in the databases reveal that this name is somewhat familiar in Italy and related to freedman. ${ }^{\text {I45 }}$ Its origin is uncertain, but might be Latin. However, it is suffice that he is recorded as a master of the the slave Quintus and because of that, likely a Roman citizen

The monument is dated to the ist half of the ist century AD.

\section{Funerary monuments to Lucius Sellius and Plautia Tertulla}

This monument (CIL V 502, Inscr. It. X. 3.22) survives only as drawing. It was seen by Orsato and Carli, but now it happens to be lost. The inscription reads:

L(ucio) Pa[...] Sellio

Plautiae Tertullae

[...] senif(ilio)

merentiposuit

"To Lucius Pa Sellius, to Plautia Tertulla, son, deserved made it

This funerary monument mentions three people in total, but only two have a preserved name in the inscription.

I44 Mócsy, Nomenclator provinciarum Europae Latinarum et Galliae Cisalpinae, 243; Lőrincz, Onomasticon provinciarum Europae Latinarum, vol. IV, 168.

I45 CIL III 157; CIL VI 1057; CIL VI 8578; CIL VI 9915; CIL VI 18181; CIL VI 20473; CIL VI 27443; CIL IX 3246; CIL XIV; AE 1920, o.105.
First is Lucius Sellius. His praenomen very common, but his nomen gentile is not fully preserved and can only be guessed. Despite that, the fact that his name was written in tria nomina formula means that he was a Roman citizen.

Cognomen Sellius is relatively often attested in Italy and might be of Latin origin. It is popular among former slaves, but more often as nomen gentile a than as cognomen. ${ }^{146}$

Plautia Tertulla, bearing a common name formula for woman was also a Roman citizen.

Name Plautia is a common Roman name and of Latin origin. Same can be said for Tertulla, which is a nickname derived from Tertia, which in turn derives from the pracitce of giving names in bigger families. ${ }^{147}$

Both Lucius Sellius and Plautia Tertulla being citizens with Roman names, it can be concluded that they might have immigrated to Aegida sometime during the first half of ist century AD.

\section{Stone slab with inscribed names}

This monument (Inscr. Inscr. It. X. 3. 17) is stone slab without a frame made in Aurisina limestone (height: $0,30 \mathrm{~m}$; Width: $0,31 \mathrm{~m}$; thickness: $0,13 \mathrm{~m}$ ). The slab is damaged and the letters are inscribed loosely and are worn. It was found in the atrium of the Museum of Koper where it is now kept. The inscription reads:

$$
\begin{aligned}
& \text { [---Co]rnelius } \\
& \text { [---]us } \\
& {[---] s} \\
& {[---] u[---]} \\
& \text { "[Co]rnelius" }
\end{aligned}
$$

The only word that can be dicserned is the name Cornelius. It is a true Roman name of Latin origin. This name was very popular and belongs to one of the oldest Roman names. Due to its popularity, it probably belonged to a Romanized member of Aegida, who was likely a citi-

I46 Mócsy, Nomenclator provinciarum Europae Latinarum et Galliae Cisalpinae, 259; Lörincz, Onomasticon provinciarum Europae Latinarum, vol. IV, 63

147 Matijašić, Uvod u latinsku epigrafiju,61-62. 
zen, maybe even an immigrant from other parts of Italy.

The monument is dated to Ist half of Ist century AD.

\section{Classification of inscriptions and monuments}

The inscriptions in this work can be classified into four categories based on its type: funerary, dedicatory, building inscription and document. Although the inscriptions are analyzed minutely in the text, short overview of types is presented.

Concerning the monuments, the majority of them were made in local Aurisina or some other Istrian limestone, like Grožnjan or local Koper stone. Only one monument, the bronze plate, was made from metal.

\section{Funerary inscriptions}

Funerary monuments make up the majority of inscriptions found in the Koper area and presented in this work. This fact is not suprising, since the vast majortiy all Roman inscriptions are of funerary character, especially outside of Rome and even more so in the provinces. The inscriptions found in Koper and its vicinity, don't stand out in any way and usually contain the information about the deceased, his family and sometimes the person who erected the monument.

One inscription (No. 2I) is a damaged monument which only mentions two people. Due to damage the inscription is only partially preserved and it is not known certainly whether it is of the funerary or maybe of some other character.

The funerary monuments themselves were made in few simple shapes: stele (inscribed plate), ara (rectangular altar, often for votive purposes), cippus (rectangular or any other geometrically shaped tombstone) and parts of the sacrophagus (coffin for the corpse of the deceased).

\section{Dedicatory inscriptions}

The nature of dedicatory inscriptions are often related to the happy fullfilment of the vow taken before some journey, bussiness or other venture, whi- ch ended favorably for the the person who then erected the monument to thank the gods and fulfill his part of the vow. This is further confirmed by the use of VSLM abbreviation. This type of monument is found all over the Empire and due to its popularity, it is not surprising for them to be found in the urban center like Aegida, although they are still significantly less represented than the funerary inscriptions.

Three inscriptions presented in this work are of votive character, all of which mention deities.

Monument dedicated to Silvanus Augustus (No. 2) was erected by Quintus Appuleius Epagathus, a freedman.

Another monument was erected by Quintus, slave of Lucius Protoctetus, who fullfilled the vow to goddess Nemesis (No. 22).

Only one monument (No. 2) found in Koper is dedicated to an oriental deity, in this case an Egyptian godess Isis. It was erected by Lucius Valerius Memor, who also served as sevir Augustalis, a priest of the imperial cult and by the information in the inscription, a distiguished member of the society in the 2 nd century AD.

\section{Building inscriptions}

This type of inscription often mentions an emperor or a magistrate who funded the construction work of some public building. This was a very common way of commemorating a donation for a public cause, so that the benefactor was known and not forgotten by the community to which he served.

One building inscription (No. 5) mentions a certain Sextius Brinniarius Certus. It also reveals that is a portico was built at the expense of the above mentioned citizen.

\section{Documents}

Documents (Latin acta) were a type of inscriptions which had legal importance and included treaties, laws but also calendars and military diplomas.

Bronze plate found in Arjol near Koper (No. 17) is a rare and important type of inscription for this area. It is probably a legal document which is 
Table s. Origin of names on the inscriptions from Koper

\begin{tabular}{|c|c|c|c|c|}
\hline Roman & Celtic & Greek and oriental & Indigenous & Uncertain \\
\hline Lucius Valerius Memor & S. Brinniarius Certus & Sal(via?) Nicostrata & Q. Cervius Fidelis & Calla or Galla \\
\hline Quintus & S. Pedanius Seneca? & C. Calpurnius Alexsa & Magaplinus & \\
\hline $\operatorname{Pup}($ inia) Forens[is] & & C. Lorentius Tesifon & Raecus & \\
\hline C. Titius & & $\begin{array}{l}\text { Q.Appuleius Epagat- } \\
\text { hus }\end{array}$ & P. Acisinus Venius & \\
\hline P. Aelio Victori & & L. Publicius Syntropus & P. Sardius Prudens & \\
\hline P. Aelius Quartus & & & & \\
\hline Pistor & & & & \\
\hline Flaminia & & & & \\
\hline Maesia & & & & \\
\hline C. Calpurnius Frugi & & & & \\
\hline Sabinnaeus & & & & \\
\hline Celotis Naevola? & & & & \\
\hline L. Herennius & 0 & & & \\
\hline L. Priscus & & & & \\
\hline C. Lorentius & & & & \\
\hline Lucida Dignitas & & & & \\
\hline Tullia Privata & & & & \\
\hline Tullia Septimina & & & & \\
\hline Marcella & & & & \\
\hline Maxima & & & & \\
\hline Tertia & & & & \\
\hline S. Pedanius Seneca? & & & & \\
\hline L. Protoctetus? & & & & \\
\hline Cornelius & & & & \\
\hline Baburia Plotia & & & & \\
\hline Tertulla & & & & \\
\hline Lucius Sellius & & & & \\
\hline
\end{tabular}

related to the granting of the citizenship to the indigenous family of Magaplines. ${ }^{148}$

\section{Classification of names mentioned in the inscriptions}

The names on the inscriptions found in Aegida were already a topic of research with published re-

I48 Starac, "Pitanje istočne granice Cisalpinske Galije i odnos općina Tergeste i Egida”, 3 I sults which indicate that the vast majority of names were Roman, ${ }^{149}$ so the following table gives only a broad overview of names which were analyzed in the article. It is important to point out that this table gives only a simple classification of names, while assumptions about social, legal and

I49 Starac, "Pitanje istočne granice Cisalpinske Galije i odnos općina Tergeste i Egida", 28-29. 
Table 2. Natural born citizens from Aegida

\begin{tabular}{|c|c|c|}
\hline Name & Monument & Datation \\
\hline Pup(inia) Forens[is] & Inscr. It.X.3.6; CIL V 487 & Ist century AD \\
\hline Sextius Brinniarius Certus & Inscr. It.X. 9. 6; CIL V 489 & Ist century BC- early ist century AD \\
\hline Publius Aelius Victor & Inscr. It.X.3.7; CIL V 492 & 2nd century AD \\
\hline Publius Aelius Victor & Inscr. It. X.3. 8; CIL V 493 & 2nd century AD \\
\hline Lucius Herennius & Inscr. It. X. 3. 19; CIL V 499 & Ist century AD \\
\hline Lucius Priscus & Inscr. It.X.3.19; CIL V 499 & Ist century AD \\
\hline Lucida Dignitas & Inscr. It.X.3.23; CIL V 504 & 3 rd century AD \\
\hline Tullia Privata & Inscr. It. X.3.23; CIL V 504 & 3 rd century AD \\
\hline Tullia Septimina & Inscr. It. X. $3.23 ; \mathrm{CIL} \mathrm{V}_{504}$ & 3 rd century AD \\
\hline Caius Titius & Inscr. It. X.3.31; CIL V 486 & early ist century AD \\
\hline Sextius Pedanius Seneca & Inscr. It.X. 3.34 & late ist century BC \\
\hline Cornelius & Inscr. Inscr. It. X. 3. 17 & Ist half of ist century AD \\
\hline Plautia Tertulla & Inscr. It. X.3.22, CIL V 502 & first half of ist century AD \\
\hline
\end{tabular}

geographical origin of the population is discussed further in the text.

\section{Socio-legal status of population on the basis of inscriptions}

Aboundance of information about social and legal status of the population of Aegida is available from the inscriptions analyzed in this work.

The population is divided into four socio-legal classes: natural born citizens, freedman and their descendants, former peregrines and slaves. It is important to point out that the majority of people mentioned in the inscriptions are citizens. This is confirmed mostly by the use of tria nomina naming system or by the information from the inscription itself, which reveals if the person was a former slave and gained the citizenship by the way of manumission. The high number of citizens reflects the legal status of the community and the level of Romanization the area achieved in the Principate, in some cases even in its early phases. ${ }^{150}$

I50 Starac, "Pitanje istočne granice Cisalpinske Galije i odnos općina Tergeste i Egida”, 29.

\section{Natural born citizens}

This category inculdes people who were born with citizenship but were not descendants of freedman. They are made up mostly of Romanized indigenous population who adopted Roman nomenclature, immigrants from other parts of Italy, people who were granted citizenship by municipal right or owners of the freed slaves only mentioned in the formula used to denote freedman. This socio-legal category of population is the most numerous on the inscriptions found in Koper and its vicinity.

People born with citizenship are recorded with their full name, tria nomina formula (which is not always preserved in the inscription due to damage) or other indications, such as tribal affiliation with a Roman cognomen.

The other category of inscriptions includes people who are just mentioned as owners of former slaves or whose name can be guessed on the basis of the freedmans praenomen and gentilicum: Quintus Appuleius (No. 2), Lucius Publicius (No. 4), Gaius Calpurnius Frugi (No. Io), Quintus Cervius (No. II), Gaius Lorentius (No. I4), Maxima, Marcella and Tertia (No. I7), Publius Sardius (No. 20) and Lucius Protoctetus 
Table 3. Names of freedman

\begin{tabular}{|c|c|c|}
\hline Name & Monument & Datation \\
\hline Lucius Valerius Memor & Inscr. It.X. 3. I; CIL V 484 & 2nd century AD \\
\hline Quintus Appuleius Epagathus & Inscr. It. X.3.2; CIL V 485 & Ist - 2nd century AD \\
\hline Lucius Publicius Syntropus & Inscr. It. X. 3. 6; CIL V 488 & mid ist century AD \\
\hline Sal(via?) Nicostrata & Inscr. It. X.3.8; CIL V 493 & 2nd century AD \\
\hline Titus Pistor, Flaminia, Maesia & Inscr. It.X. $3 \cdot 13$ & first half of the ist century AD \\
\hline Caius Calpurnius Alexsa & Inscr.It.X.3. I4; CIL V 495 & Ist century AD \\
\hline Sabinnaeus & Inscr.It.X.3. I4; CIL V 495 & Ist century AD \\
\hline Quintus Cervius Fidelis & Inscr. It. X. 3. 16; CIL V 496 & Ist century AD \\
\hline Caius Lorentius Tesifon & Inscr. It.X. $3.20 ;$ CIL V 500 & 3 rd century AD \\
\hline Magaplines & Inscr. It. X.3.30; CIL V 50I & Ist century AD \\
\hline Galla? & Inscr. It. X.3.32; CIL V 491 & Ist century AD \\
\hline Publius Sardius Prudens & Inscr. It.X.3.33; CIL V 503 & early ist century AD \\
\hline Celotis Naevola? & Inscr. It.X. 3. I8; CIL V 498 & ist AD \\
\hline
\end{tabular}

(No. 22). Although their names are not always recorded fully in tria nomina form, they must've been Roman citizens, otherwise they couldn't have owned slaves. It can be assumed that they owned land or ran bussinesses which were worked by slaves in the Aegida area.

\section{Freedman and their descendants}

This social group is the second most numeros class of citizens mentioned on the inscriptions. Freedman were the most mobile social class and their presence tell both about need for slave labor and the increasing number of citizens, which can be related to the rising of all aspects of urban structure of Aegida. Since they form a special social class, they are categorized separately from the natural born citizens, although their legal status and that of their descendats, is almost the same.

Almost half of inscriptions found in Koper and its vicinity mention a freedman.

\section{Former peregrines}

Only one inscription (No. 19) found in Koper can be ascribed to the former peregrine with some certainty. His name is Publius Acisinius
Venius, which is likely of Illyrian and therefore of indigenous origin. Along with the filiation of the father in the genitive case, which is very typical for peregrines, ${ }^{151}$ it can be conjectured that this individual was maybe a former peregrine.

Also, Publius Aelius Quartus (No. 7) might have been a descendant and therefore a freeborn citizen or a peregrine who was conferred citizenship by Hadrian.

\section{Slaves}

In the category of non-citizen population, only one inscription (No. 22) mentions a slave named Quintus, whose master is Lucius Protoctetus. It is interesting that the only inscription mentioning a slave is a votive dedication to Nemesis and that the mentioned slave has a true Roman name, unlike other slaves, whose names are mostly of oriental or Greek origin. It is possible that this particular individual was a Roman who lost his freedom due to debt or some other circumstance. Because of the lack of information, this assumption cannot be confirmed.

I5 I Julijana Visočnik, "Names on Celeian inscriptions in numbers and tables - a comparison between town and ager", Opuscula Archaeologica $34(2010), 232-233$. 
Other possible slave mentioned on the inscription from Aegida, might have been Galla, wife of Publius Acisinus Venius (No. 19), since she bears a single-part name. However, since her husband was a citizen, marriage could not have been legal if they both were not citizens, so it is also possible that Galla was a freedwoman, as already classified that way above.

\section{Geographical origin of population based on the origin of the name}

It is very hard to connect person to the geographical origin only on the basis of its name, especially if the that origin is not mentioned in the inscription with the usual formula which accompanies the foreigners (natione, domo or tribu which is certainly is assigned to some other community), their profession (e. g. soldiers) or a votive dedication which is certainly of foreign origin. ${ }^{152}$ In conjecture with the works of other authors, very broad outline of the geographic origin of population of Aegida can be discerned.

\section{Indigenous population}

Inscriptions which mention indigenous population are the most numerous in this classification and are already published as such by other authors. ${ }^{153}$ On the basis of their names (Cervius, Acisinus, Sardius, Magaplines, Raecus) which they received as freedman by their former masters, it can be conjecutred that the former owners also bore indigenous names, typical for Istria and in some cases Liburnia.

Because the onomastical studies in the Illyrian and Liburnian nomenclature were the topic of interest to a number of archeologists and linguists, it is relatively easy to pinpoint the origin of the population on the basis of their names in those areas. Outside of it, the area of possibility and uncertainty is entered, so only the broadest outline can be given.

152 Visočnik, "Names on Celeian inscriptions in numbers and tables", 277.

I53 Krahe, Lexikon Altillyrischer Personennemen, 28; Jürgen Untermann, Die Venetischen Personennamen, 17; Starac, "Pitanje istočne granice Cisalpinske Galije i odnos općina Tergeste i Egida”, 29.

\section{Italics}

Inscriptions which mention population of possibly Italic origin are hard to determine and are likely connected to the owners of former slaves. If the gentilicium is not of indigenous of Imperial origin, it is likely Itallic and related to colonists who owned land or were immigrants, in this case from other parts of Italy ${ }^{154}$ who bore true Roman names: member of the Pupinia tribe and cognome Forensis (No. 3), Gaius Calpurnius Frugi (No. Io) Maxima, Marcella and Tertia(No. 17) and maybe Lucida Dignitas (No. 15), Baburia Plotia and the Taronians (No. 8). The owners whose name was given to the freedman is not included in Table 4.

\section{Orientals}

Although most slaves have a name of oriental or Greek origin, studies have found that this alone cannot be a sign of their geographical provenance. ${ }^{155}$ Slaves from the western parts of the Empire also were given Greek names and it seems that this practice was common for the whole social class. On the inscriptions from Koper (No. 4 and I4), it can be assumed that two people were maybe from the East or Africa.

Lucius Publicius Syntropus (No. 4) was likely of oriental origin, although he bears a gentilicum very often found in the Istria and the Cisalpine Gaul. This assumption is made on the basis of the cognomen he bore, which is of Greek origin, his status as a freedman and the function of archigallus, which is a priestly service of Magna Mater. Due to its oriental provenance and populatiry in the East, it is possible that Lucius Publicius Syntropus came from the East as a slave, was manumitted and then served as a priest in the oriental cult.

Second inscription mentions Caius Lorentius Tesifon (No. I4), who might have been brought as a prisoner during the campaign of Septimius Severus against the Parthians in 197 AD. Although this seems as sa far-fetched assumtpion, the name and the datation of the monument open this possibility.

\footnotetext{
I54 Visočnik, "Names on Celeian inscriptions in numbers and tables", 232.

I55 Matijašić, Uvod u latinsku epigrafiju, 62.
}

$\sqrt{2}$

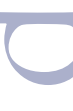

O

\author{
$f$
}

\section{(} (a) 
Table 4. Names divided on the basis of their possible geographical origin

\begin{tabular}{|c|c|c|c|}
\hline Indigenous & Italic & Oriental & Western \\
\hline Quintus Cervius & Pup(inia) Forens[is] & Lucius Publicius Syntropus & Sextius Brinniarius Certus \\
\hline Magaplines & Gaius Calpurnius Frugi & Caius Lorentius Tesifon & Sextius Pedanius Seneca? \\
\hline Publius Sardius Prudens & Lucida Dignitas? & & Caius Titius \\
\hline Raecus & Cornelius & & Lucius Valerius Memor \\
\hline Maxima, Marcella Tertia & $\begin{array}{l}\text { Baburia Plotia } \\
\text { Plotianus } \\
\text { Iuliane }\end{array}$ & & \\
\hline
\end{tabular}

\section{Westerners}

Similar as with the orientals, it is very hard to determine the geographical origin of the people who bear names mentioned only in the west. They might or might not have been from the far western areas of the Empire, since Celtic names which they usually have, were very popular in surrounding areas like Northern Italy and Noricum.

Lucius Valerius Memor (No. I), Sextius Brinniarius Certus (No.s) and maybe Sextius Pedanius Seneca (No. 2I) offer a possibility that the persons mentioned were maybe of Celtic or western origin.

Only one inscription (No. 18) found in Koper is undoubtly of western and Celtic provenance. It is the funerary monument of Caius Titius, a legionnaire from Vienna in Gaul, who explicitlyhstates this fact in the inscription. He served in Is legion of Appolonians and probably after his service, retired in vicinity of Koper like his other comrades.

\section{Conclusion}

Onomastical analysis of inscriptions found in Koper and its vicinity reveal that ancient Aegida was a romanized urban community, situated on the island where today historical center of Koper stands. While relativley numerous compared to size and apparent importance during the antiquity, due to renaissance and humanistic habit of collecting and transfering Roman monuments, the information gained from the analysis can prove problematic and unreliable. It has been pointed out that there is no solid proof that any of the monuments were found in the archaeological context or on the island itself. However, a very broad outline can be discerned if the fact that Aegida was a town with the municipial status at least from the time of Augustus and that the monuments are related to its population, and not to that of nearby Tergeste.

The types of inscriptions fall into four basic categories, sorted by their numbers: funerary, dedicatory, building inscriptions and documents.

The most important fact that stems from the onomastical analysis of inscriptions is the number of Roman names and the number of citizens, both natural-born and freedman. These two categories of onomastical and social aspects reveal that the population was already quite romanized already in the Early Principate. While not new, ${ }^{156}$ this conclusion cannot be overlooked in any work concerning ancient Aegida.

Roman names are the most numerous and make up the majority of all names inscribed in the inscriptions. Other categories of names include those of Greek or oriental origin, Celtic, indigenous and of unknown origin. It is important to point out that indigenous names were often borne by freedman, which is important because they inherited them from their masters. Landowners of bussinessman who were citizens, but were still named in their native fashi-

I56 Starac, "Pitanje istočne granice Cisalpinske Galije i odnos općina Tergeste i Egida”, 28. 
on, further contributes to the fact that the Romanization was quick and effective.

Concerning the socio-legal picture of the population of Aegida, citizens which are made of natural born and freedman are the most numerous social group, with peregrines and slaves being almost nonexistant on the inscriptions. However, this can be a misleading and cannot mean they were not represented in the population, especially if the number of freedman is taken into consideration.

The mobility of the social hierarchy is also witnessed by the magistracies mentioned in the inscriptions, which are considered to belong to the political subjects of Aegida, and not Tergeste.

While being very hard to pinpoint excatly, a short oveview of the geographical provenance of people mentioned in the inscriptions can be discerned. These include indigenous population and Italics who were probably landowners and immigrants. While being relaitvely numerous, freedman with oriental and Greek names, cannot immediately be held to come from the East. Only two indviduals were likely of oriental origin. The last group includes the population which probably came or were native to the areas in the West (Hispania and Gaul). Only one individual is certainly from Gaul, as it is stated in his monument. His inscription is also the only one mentiabing a profession, in this case a legionnaire of is legion of Appolonians.

Although Aegida seems to have lost its importance as it did not appear in the maps, itineraries and historical sources, inscriptions from the period of Principate reveal that it was an urban community with vibrant social structure who quickly adopted the Roman way of life, which is reflected in their names on the monuments they erected, both of which are important signs of Romanization.

\section{Povzetek}

Članek ponuja onomastično analizo štiriindvajsetih napisov, ki so bili izkopani v Kopru ali v njegovi bližini. Vsi napisi so že objavljeni v ustreznih korpusih latinskih besedil. Z onomastično analizo epigrafskih spomenikov in napisov članek zbira razpoložljive podatke o socialno-pravnem statusu in možnem geografskem poreklu prebivalstva v stari Egidi (današnjem Kopru). Ti spomeniki dokazujejo, da so območje v okolici Egide naseljevali rimski državljani, osvobojenci, sužnji in priseljenci. Izvor ljudi, navedenih v napisih, kaže na pripadnike avtohtonega prebivalstva, ki so bili do neke mere romanizirani, a tudi na prebivalce z vzhoda, zahoda in priseljence iz drugih delov Italije. Med temi so tudi razni posamezniki, ki so opravljali razne drževne funkcije. Predstavljene so tudi kratka zgodovina Egide in okoliščine odkritja spomenikov. Vsi napisi iz obdobja principata.

\section{Summary}

The article gives an onomastical analysis of twenty-four inscritpions found in or in the vicinity of Koper, all of which are already published in the relevant corpora of Latin texts. Thorugh the onomastical analysis of epigraphical monuments and inscriptions, article discernes available information about socio-legal status and the possible geographical origin of the population in ancient Aegida (todays Koper). These monuments reveal that freeborn citizens, freedman, slaves and peregrines inhabited the region around Aegida in antiquity. Origin of the people mentioned in the inscriptions include indigenous population romanized to certain extent, orientals, westerners and immigrants from other parts of Italy. There are also several individuals who are recorded to have preformed certain magistracies. Short history of Aegida and the nature of finding of monuments is also presented. All inscriptions are dated to the period of the Principate.

\section{Bibliography}

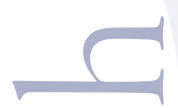

Alföldy, Geza. Die Personennamen in Der Römischen Provinz Dalmatia. Heidelberg: Winter, 1969.

Bodel, John P. Roman Brick Stamps in the Kelsey Museum. Ann Arbor: University of Michigan Press, 1983.

Cunja, Radovan. "Koper, Kapucinski vrt.” Arbeološki pregled (1986) 1987, I18-120.

Degrassi, Attilio. Abitati Preistorici E Romani Nell'agro Di Capodistria E Il Sito Dell'antica Egida. Parenzo: G. Coana e Figli, 1933. 
Degrassi, Attilio. Inscriptiones Italiae, Vol. X., Regio X, Fasc. III. Roma: Libreria Dello Stato, 1936.

Farnum, Jerome H. The Positioning of the Roman Imperial Legions. Oxford: Archaeopress, 2005.

Glavičić, Miroslav. "Tri rimskodobna natpisa iz Senja." Senjski zbornik 23 (1996), 19-34.

Hornblower, Simon. The Oxford Classical Dictionary. 3rd ed. Oxford: Oxford University Press,

1996.

Kajanto, Iiro. The Latin Cognomina. Societas Scientiarum Fennica, Commentationes $\mathrm{Hu}$ manarum Litterarum, XXXVI 2: Helsinki 1965.

Katičić, Radoslav. "Zur Frage der keltischen und pannonischen Namengebiete im romischen Dalmatien." Godišnjak Centra za Balkanološka ispitivanja III (1965), 53-76.

Karković Takalić, Palma. "Period of Introduction and Role of Archigalli in Context of the Inscription of L. Publicius Syntropus from Koper. "Archaeologia Adriatica 6 (20I2): 87-105.

Keppie, Lawrence J. F. Understanding Roman Inscriptions. Baltimore: Johns Hopkins University Press, 1991.

Krahe, Hans. Lexikon Altillyrischer Personennemen. Heidelberg: Carl Winter's Universitätsbuchhandlung, I929.

Križman, Mate, Rimska imena u Istri: osobna imena na istarskim natpisima iz rimskog doba. Zagreb: Latina Et Graeca, 1991.

Lörincz, Barnabas, Redö, Ferenc. Onomasticon provinciarum Europae latinarum: Aba-Bysanus, vol. I. Budapest: Archaeolingua Alapítvány, 1994.

Lörincz, Barnabas. Onomasticon provinciarum Europae Latinarum, vol. II: CABALICIUS-IXUS. Wien: Forschunsgesellschaft Wiener Stadtarchäologie, 1999.

Lörincz, Barnabas. Onomasticon provinciarum Europae Latinarum, vol. III: LABAREVS-PYTHEA. Wien: Forschunsgesellschaft Wiener Stadtarchäologie, 2000.
Lörincz, Barnabas, Onomasticon provinciarum Europae Latinarum, vol. IV: QVADRATIA-ZVRES, Wien: Forschunsgesellschaft Wiener Stadtarchäologie, 2002.

Mainardis, Fulvia, E ora sono tutti Romani. L'evoluzione delle formule onomastiche nelle iscrizioni della Transpadanaromana. Roma, 1997. Matijašić, Robert. Uvod u latinsku epigrafju. Pula: Filozofski fakultet u Puli, 2002.

Mócsy, Andras, Pannonia and Upper Moesia: A History of the Middle Danube Provinces of the Roman Empire. London; Boston: Routledge and K. Paul, 1974.

Mócsy, Andras, Feldmann, Reinhard. Nomenclator Provinciarum Europae latinarum et Galliae Cisalpinae: cum indice inverso. Budapest: Népművelési Propaganda Iroda, 1983.

Perinić, Ljubica. "O zavjetnom natpisu Minervi "Opuscula Archaeologica 23-24 (2000), 417424.

Ritterling, Emil. "Legio" in RE XII, II86 - I829. Stuttgart: J. B. Metzler, 1924-1925.

Rossignano, Maria Silvia. "I Praefecti iure dicundo nell'Italia settentrionale." in Epigrafia. Actes du colloque international d'epigraphie latine en mémoire de Attilio Degrassi pour le centenaire de

sa naissance. Actes de colloque de Rome (27-28 May 1988) (Rome: École Française de Rome, 199I), 515-537.

Salway, Bennet. "What's in a Name? A Survey of Roman Onomastic Practice from c. 700 B.C. to A.D. 700." Journal of Roman Studies 84 (1994): I24-I45.

Schulze, Wilhelm. Zur Geschichte lateinischer Eigennamen. Berlin; Zürich; Dublin: Weidmann 1966.

Smith William, Wayte William, ed., G. E Marindin. A Dictionary Of Greek And Roman Antiquities. London:John Murray I8go.

Suić, Mate. Anticki grad na istočnom Jadranu. Zagreb: Sveučilisna naklada Liber, 1976.

Starac, Alka. "Pitanje istočne granice Cisalpinske Galije i odnos općina Tergeste i Egida." Histria Archaeologica 24-25 (1993 - 1994): 5-57. 
Šašel, Jaroslav, Weiler, Ingomar. "Zur augusteisch-tiberischen Inschrift von Emona", Carnuntum Jabrbuch 8 (1963-1964), 40-42.

Šašel, Jaroslav. "Koper." Arheološki vestnik 25 (1976): 446-460.

Šašel, Jaroslav. "Zur Frühgeschichte der XV. Legion und zur Nordostgrenze der Cisalpina zur Zeit Caesars.” Archäeologisch-epigraphische Studien I (1985): 547-555.

Šašel-Kos, Marjeta. "The Isth Legion at Emonasome Thoughts." Zeitschrift für Papyrologie und Epigraphik Io9 (1995): 227-244.

Taylor, Lily Ross. "Augustales, Seviri Augustales, and Seviri: A Chronological Study." Transactions and Proceedings of the American Philological Association (1914), 231-253.

Untermann, Jürgen. Die Venetischen Personennamen. Wiesbaden: Harrassowitz, 196I.

Visočnik, Julijana. "Names on Celeian inscriptions in numbers and tables - a comparison between town and ager." Opuscula Archaeologica 34 (2010).

Wilkes, John J. The Illyrians. Cambridge: Blackwell, 1992.

Wheeler, Everett L. "Legio XV Apollinaris: From Carnuntum to Satala and beyond." in Y. Le Bohec, ed., Les Légions de Rome sous le Haut-Empire (Lyon/Paris: De Boccard, 2000), 259-30.

Župančič, Matej. "Inter utrumque tuta" in $\mathrm{Ko}$ per zwishen Rom und Venedig, ed. Matej Župančič (Koper: Regionalmuseum Koper, I991) 6-II.

Župančič, Matej. "Sermin ob Rižani, pretres virov in arheoloskih podatkov." Arheoloski vestnik 36 (1985): 315-325.

\section{List of sources}

\section{Cassius Dio}

Dio's Rome: An Historical Narrative Originally Composed in Greek during the Reigns of Septimus Severus, Geta and Caracalla, Macrinus, Elagabalus and Alexander Severus: And Now
Presented in English Form, trans. H. B. Foster, J.Zonaras. New York, 1905.

Pliny the Elder

Pliny's Natural History, trans. H. Rackham, W.H.S. Jones, D.E. Eichholz. Cambridge: Harvard University Press, London: William Heinemann 1949-1954.

Ravenna Cosmography

Ravennatis Anonymi Cosmographia et Guidonis Geographica, ed. Joseph Schnetz, Marianne Zumschlinge. Stuttgart: Teubner, 1990.
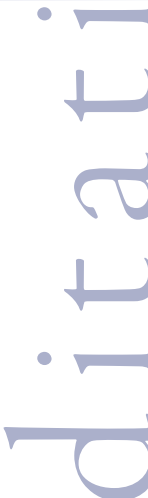

(
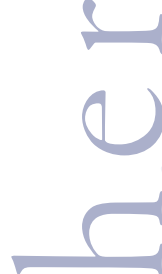